\title{
Expanding the Borders of Common Article 3 in Non- International Armed Conflicts: Amending Its Geographical Application through Subsequent Practice?
}

\author{
Martha M. Bradley*1
}

\begin{abstract}
The geographic footprint of contemporary warfare often challenges the existing understanding of the term 'non-international armed conflict', a term not defined in international humanitarian treaty law. This article examines whether the opening lines of Common Article 3 of the Geneva Conventions include a geographical requirement. Controversy surrounds this question which until recently has received little attention. The customary interpretation of Common Article 3 is that it has a geographical scope of application limited to non-international armed conflicts which take place exclusively within the borders of a single member state (internal armed conflict). The 2016 ICRC Commentaries to the First Geneva Conventions challenges this traditional view and argues in favour of a broader interpretation of the scope of application of Common Article 3. This re-interpretation recently has gained traction in scholarship. The ICRC's position serves as a possible solution to prevent a lacuna in humanitarian protection in situations where conflicts fit neither the understanding of 'international armed conflict' nor 'internal armed conflict'. By evaluating the merits of the arguments posed by the ICRC, the article assesses whether the phrase 'conflict not of an international character', as included in Common Article 3, conclusively limits its geographical application to an armed conflict occurring within the boundaries of a single state.
\end{abstract}

Keywords Common Article 3; Geographic requirement; 2016 ICRC Commentaries; Borders; Internal armed conflict; Non-international armed conflict

Information footnote: This work is based on the research supported by the South African Research Chairs Initiative of the Department of Science and Technology and the National Research Foundation of South Africa (Grant No. 98338). I am grateful to Professor Erika de Wet, Professor Jann Kleffner, Jeanique Serradinho and the anonymous reviewers for comments on earlier drafts of the article.

\footnotetext{
* $\bowtie \quad$ Martha M. Bradley

mmbradley@outlook.com

1 Doctoral candidate, Department of Public Law, University of Pretoria, Pretoria, South Africa

2 Non-resident SARChI associate, Institute for International and Comparative Law in Africa, University of Pretoria, Pretoria, South Africa
} 


\section{Introduction}

The term 'armed conflict' is not defined in any international humanitarian law treaty. Various reasons have been offered for this lack of definition. ${ }^{1}$ The task of defining the term 'armed conflict' and, subsequently, 'non-international armed conflict' has received a great deal of attention. $^{2}$ Efforts to define the term 'non-international armed conflict', as well as the scholarly debate scrutinising these efforts, have peaked three times. ${ }^{3}$ The first critical effort to define 'non-international armed conflict' occurred post-1993 following the establishment of the International Criminal Tribunal for the Former Yugoslavia (ICTY) and the International Criminal Tribunal for Rwanda (ICTR), which provided benchmark decisions concerning the definition of the term 'armed conflicts'. ${ }^{4}$ The second effort which highlighted the need for a clear definition of armed conflict came in the years following 9/11..$^{5}$ A particularly clear example of such a post-9/11 development is the proclaimed 'war on terror' which has been described as a 'spill-over', 6 'cross-border'7 or 'transnational' ${ }^{8}$ armed conflict. The 2016 International Committee of the Red Cross (ICRC) Commentaries to the First Geneva Conventions are a response to the call for a clear understanding of the term 'non-international armed conflict' as it relates to Common Article 3. ${ }^{9}$ The urgency of this response may be attributed to these post-9/11 developments. The response of the ICRC marks the third historic peak of interest and need for clarification of the term 'non-international armed conflict'. ${ }^{10}$

Common Article 3, the oldest treaty provision to regulate non-international armed conflicts, has been the point of departure in the effort to define the term 'non-international' armed conflict, in that the provision imposes the underlying humanitarian principles of all four of the Geneva Conventions upon parties engaged in a non-international armed conflict. ${ }^{11}$

1 See Final Report on the Meaning of Armed Conflict in International Law, International Law Association: The Hague Conference: Use of Force (2010), p. 4. For a general discussion, see Fleck (2013), pp. 1201-1221.

$2 \quad$ See e.g. Kress (2012), p. 145.

3 Ibid., pp. 146-147. Kress identifies two such tracks attributed: first, to the Tadić case and, second, to the events following $9 / 11$.

$4 \quad$ Ibid.

$5 \quad$ Ibid.

$6 \quad$ See Schoberl (2015), p. 77. 'Spill-over' armed conflicts are defined as conflicts between armed forces and non-state armed groups or among non-state armed groups which spill over into the territory of a neighbouring state. Schmitt (2014), p. 11 defines 'spill-over' armed conflicts as conflicts 'in which the government armed forces penetrate the territory of a neighbouring state in order to engage organized armed groups operating in border areas'.

7 Schondorf (2004), p. 1. 'Cross-border' armed conflicts refer to conflicts in which states fight non-state groups operating from the territory of a neighbouring state without that neighbouring state exercising control over the non-state armed group.

$8 \quad$ Kress (2010), p. 245 defines a transnational armed conflict as a 'descriptive term for a phenomenon which may be defined as cross-border armed violence between a state and a (collective) non-state actor'.

$9 \quad$ ICRC, 'Commentary of 2016: Article 3: Conflicts not of an international character', https://ihldatabases.icrc.org/applic/ihl/ihl.nsf/Comment.xsp?action=openDocument\&documentId=59F6CDFA490736C1C 1257F7D004BA0EC (accessed 23 November 2016).

10 Ibid.

11 Art. 3 is common to all four the Geneva Conventions listed in sequence: the 1949 Geneva Convention I for the Amelioration of the Condition of the Wounded and Sick in Armed Forces in the Field, 75 UNTS 31; the 
Article 3 is found in all four Geneva Conventions, which are aimed at protecting civilians in armed conflict by regulating the actions of the warring parties. ${ }^{12}$ Article 3 sets out a minimum framework of rules binding on all parties to a non-international armed conflict. ${ }^{13}$ For this reason, it is often referred to as a 'convention within a convention'. ${ }^{14}$

The Tadic definition of the term 'non-international armed conflict' mirrors two of the threshold requirements indicated in the drafting history of Common Article $3 .{ }^{15}$ These requirements are the existence of a certain level of intensity of violence and a degree of organisation of the non-state party engaged in the armed conflict. ${ }^{16}$ Jurisprudence of international tribunals and courts indicates that the violence has to be of a protracted nature. ${ }^{17}$ The term 'protracted violence' necessitates that there has to be a certain level of intensity for an incident to be transformed into a non-international armed conflict. ${ }^{18}$ Essentially, the interpretation of 'protracted violence' turns on the manner in which the violence is conducted

1949 Convention II for the Amelioration of the Condition of Wounded, Sick and Shipwrecked Members of Armed Forces at Sea, 75 UNTS 85; the 1949 Geneva Convention III Relative to the Treatment of Prisoners of War, 75 UNTS 135; and the 1949 Geneva Convention IV Relative to the Protection of Civilian Persons in Time of War, 75 UNTS 287.

12 Ibid.

13 As has generally been accepted and, furthermore, confirmed by the ICJ in Military and Paramilitary Activities in and Against Nicaragua (Nicaragua v. United States), Merits, Judgment of 27 June 1986, ICJ Reports 1986, p. 14, at p. 103, para. 218, Common Art. 3 of the Geneva Conventions has acquired customary status.

$14 \quad$ Moir (2003), p. 31.

15 Final Record of the Diplomatic Conference of Geneva of 1949, Vol. II, Section B, p. 42: 'International law and conventions should apply when civil war was of such magnitude as to be full-scale war [emphasis added]'. See Pictet (1960), p. 36; Cullen (2010), p. 42. 'The Report drawn up by the Joint Committee and presented to the Plenary Assembly interprets the term "armed conflict not of an international character" as having the same meaning as "civil war". In explaining what was understood by "armed conflict not of an international character", the report states that "it was clear this refers to civil war" [...] This Report of the Joint Committee [...] is referred to here only to highlight that the terms "civil war" and "armed conflict not of an international character" were understood as possessing equivalent thresholds. This is significant, as the concept of civil war presupposes the existence of hostilities of a scale and duration similar to that of an international conflict. Situations falling short of this level of intensity required to merit the recognition of belligerency and, hence, would not qualify for application of international humanitarian law [emphasis added]'. Compare Prosecutor v. Duško Tadić aka 'Dule', Decision on the Defence Motion for Interlocutory Appeal on Jurisdiction, Case No. IT-94-1-A, A.Ch, 19 July 1998, para. 70.

16 See also Prosecutor v. Mile Mrkšić, Miroslav Radić, Veselin Šljivančanin, Trial Judgment, Case No. IT-95-13/1-T, T.Ch., 27 September 2007 for a confirmation of this test.

17 See Tadić case, above n. 15; Prosecutor v. Boškoski and Tarčulovski, Trial Judgment, Case No. IT-0482-T, T.Ch.II, 10 July 2008, para. 175; Prosecutor v. Ramush Haradinaj, Idriz Balaj, Lahi Brahimaj, Trial Judgment, Case No. IT-04-84-T, T.Ch.I, April 2008, para. 39; Situation in the Democratic Republic of the Congo in the Case of the Prosecutor v. Thomas Lubanga Dyilo, Decision on the Confirmation of Charges, Case No. ICC-01/04-01/06, Pre Trial Chamber I, 29 January 2007, para. 538; Prosecutor v. Zejnil Delalić, Zdravko Mucić also known as 'Pavo', Hazim Delić, Esad Landžo also known as 'Zenga', Judgment, Case No. IT-96-21T, T.Ch., 16 November 1998; Prosecutor v. Enver Hadžihasanović, Amir Kubara, Judgment, Case No. IT-0147-T, T.Ch., 15 March 2006; Prosecutor v. Georges Anderson Nderubumwe Rutanganda, Judgment, Case No. ICTR-96-3-T, T.Ch.I, 6 December 1999, para. 93; Prosecutor v. Alfred Musema, Judgment and Sentence, Case No. ICTR-96-13-A, T.Ch.I., 27 January 2000, paras. 248-51; Prosecutor v. Jean-Paul Akayesu, Judgment, Case No. ICTR 96-4-T, T.Ch.I., 2 September 1998, para. 627.

$18 \quad$ Ibid 
rather than on its duration. ${ }^{19}$ The drafting history of Common Article $3^{20}$ and the subsequent practice of judicial bodies ${ }^{21}$ suggest that the existence of a non-international armed conflict necessarily implies a level of organisation which the military forces of the non-state party has to satisfy. ${ }^{22}$ As an in-depth study of these two requirements falls outside the scope of this article, and because these criteria have received much scholarly attention, the present contribution will not repeat the work in much detail. ${ }^{23}$ This contribution seeks to determine the existence of a third, so-called 'geographic' Common Article 3 requirement and, if the geographical requirement exists, to give it content. Until recently, this requirement has gone unnoticed and until after 9/11 received hardly any scholarly attention.

The implication of the existence of a geographical requirement is that if Common Article 3 applies to a non-international armed conflict occurring only within the borders of a single High Contracting Party, ${ }^{24}$ the application of Common Article 3 will be suspended if the parties to the initial non-international armed conflict take the fighting beyond the borders of the High Contracting Party in which the non-international armed conflict originated. This point is illustrated by two examples based on the actors involved in the initial Common Article 3-type non-international armed conflict. First, Common Article 3 will be suspended if the parties to the initial non-international armed conflict are the state's armed forces fighting on its own territory on behalf of its government against a non-state actor (or several non-state actors) and such a conflict spills over into the territory of a second state. Consequently, such state armed forces are now involved in a conflict against a non-state actor (or actors) outside its own territory. ${ }^{25}$ The second example is where two or more non-state actors cross a border into a second territory. It is possible that a separate non-international armed conflict regulated by Common Article 3 may commence, but only if the required minimum threshold requirements are met. Common Article 3 will apply only once the intensity threshold has been met and not in the time frame between when the border was crossed and the intensity

19 Haradinaj case, above n. 17, para. 49; 2016 ICRC Commentaries, above n. 9, paras. 88-94. Para. 90 stipulates: 'The duration of hostilities is thus appropriately considered to be an element of the assessment of the intensity of the armed confrontations. Depending on the circumstances, hostilities of only a brief duration may still reach the intensity level of a non-international armed conflict if, in a particular case, there are other indicators of hostilities of a sufficient intensity to require and justify such an assessment.'

20 Final Record, above n. 15, paras. 44, 77. For a scholarly discussion of the Final Record of the Diplomatic Conference of Geneva of 1949 and the Pictet Commentaries in relation to Common Art. 3, see Cullen (2004), pp. 194-195.

21 Boškoski case, above n. 17, paras. 199-203. See also n. 19.

22 See Sivakumaran (2014), pp. 171-174 for an analysis of the organisational criterion.

23 Pejic (2011), p. 202; Kress (2010), p. 245; Jinks (2003), p. 1; Sassòli (2006); Schmitt (2014), p. 1; Cullen (2005), p. 66; Arimatsu and Choudhury (2014), p. 1. See also 2016 ICRC Commentaries, above n. 9, paras. 88-94. Para. 90 stipulates that ' $[\mathrm{t}]$ he duration of hostilities is thus appropriately considered to be an element of the assessment of the intensity of the armed confrontations. Depending on the circumstances, hostilities of only a brief duration may still reach the intensity level of a non-international armed conflict if, in a particular case, there are other indicators of hostilities of a sufficient intensity to require and justify such an assessment.'

$24 \quad$ Ibid.

25 An in-depth analysis of the consequences of what this situation would be defined as under international law falls outside the scope of the article. However, in terms of the traditional interpretation of Common Article 3 , such a situation would not be a non-international armed conflict. 
requirement was satisfied. ${ }^{26}$ These conflict situations will no longer be classified as armed conflicts within the scope of application of the law of armed conflict, as such conflicts fit into neither the definition of 'international armed conflict' as defined by Common Article 2 nor into the definition of 'non-international armed conflict' as derived from either Common Article 3 or from Additional Protocol II. $^{27}$ As a result, such conflict situations are not regulated either by the law of international armed conflict or the law of non-international armed conflict and, arguably, this situation creates a lacuna in the law. ${ }^{28}$ The changing footprint of armed conflict post-9/11, ${ }^{29}$ together with the publication of the recent 2016 ICRC Commentaries on the First Geneva Conventions, prompts the need to revisit the definition of the term 'armed conflict' as included in Common Article 3.

This article analyses whether Common Article 3 of the Geneva Conventions includes a geographical requirement. In examining Common Article 3, the ordinary meaning of the text, ${ }^{30}$ the context ${ }^{31}$ and the object and purpose ${ }^{32}$ of the provisions will be considered in accordance with the general principles of treaty interpretation. Between 1949 and 2001, the majority of non-international armed conflicts in fact fit the classic mould of internal armed conflict in that they occurred between a state's armed forces and an organised armed group or between different armed groups within the borders of a single state. ${ }^{33}$ Many post-9/11 armed conflicts do not fit this mould; many have been fought between a single state and an organised armed group or groups but have spilled over that state's borders into a second (or more) state or states. ${ }^{34}$ The article first poses the question whether the interpretation of the phrase 'conflict not of an international character' and 'occurring in the territory of one of the High Contracting Parties', as included in Common Article 3, conclusively sets out its

26 The intensity of the non-international armed conflict would not necessarily diminish once the border has been crossed, but such a possibility exists. This is possible, for example, if a small section of the state's armed forces and a few members of the organised armed group belonging to the non-state party to the conflict cross the border and shots are fired outside the territory of the High Contracting Party, resulting in a negligible death toll. In such a case, arguably the conflict on the territory of the second state fails to meet the intensity requirement. However, it may over time become systematically more violent and could escalate to the extent that the intensity requirement is satisfied. It is only once the intensity requirement is met that Common Article 3 will apply. On the other hand, it remains possible that the intensity of the fighting is continuously sustained before, during and after the crossing of the border. In essence, a new evaluation will be conducted regarding both the intensity and organisational requirements once the border of the High Contracting Party is crossed into foreign territory and, indeed, it can be that some time lapses before the fighting on the other side of the border satisfies these requirements, if ever.

27 Geneva Conventions, above 11.

28 International Committee of the Red Cross, "How is the term "armed conflict" defined in international humanitarian law?', International Committee of the Red Cross (ICRC) Opinion Paper, March 2008, p. 5; Schmitt (2014), p. 9; Sassòli (2006), p. 9; Schondorf (2004), p. 78.

29 This definition also is challenged by the conflict in Lebanon and the current armed conflict in Syria.

301969 Vienna Convention on the Law of Treaties, 1155 UNTS 331, Art. 31(1). For an in-depth discussion of Art. 31(1), see Sorel and Bore Eveno (2011), pp. 804-837.

$31 \quad$ Vienna Convention, above n. 30, Arts. 31(2) and 31(3). For an in-depth discussion of Art. 31, see Sorel and Bore Eveno (2011). In The MOX Plant case (Ireland v. The United Kingdom), Provisional Measures, Case No. 10 ITLOS, 3 December 2001, para. 51.

32 Vienna Convention, above n. 30, Art. 32. For an in-depth discussion of Art. 32, see Le Bouthillier (2011), pp. 841-863.

33 Kress (2012).

$34 \quad$ Ibid. 
geographical reach as limited to an armed conflict occurring within the boundaries of a single state. ${ }^{35}$ The second interpretative question is whether subsequent practice potentially expands the scope of application of Common Article 3 to apply equally to non-international armed conflicts other than internal armed conflicts. These questions seek to determine whether there is merit in the ICRC's argument which challenges the status quo concerning the inclusion of a geographical requirement in the text of Common Article 3 or, should such a geographical requirement exist, that state practice is changing this interpretation. ${ }^{36}$

The article is divided into three sections, excluding this introduction. First, it discusses the traditional interpretation of the geographical scope of Common Article 3. Second, it considers the alternative reading of the opening lines of Common Article 3 in light of subsequent practice. Finally, some conclusions are offered.

\section{Traditional Interpretation of the Geographic Scope}

At this juncture it is important for the author to explain her understanding of the interpretation as well as the interplay between the terms 'civil war', 'internal armed conflict' and 'non-international armed conflict' in relation to Common Article 3 as used in the article. These three terms have been viewed as synonyms and used interchangeably to refer to situations of armed conflict fought between a single state's armed forces and one or multiple organised armed groups or between two or more organised armed groups within the confines of a single state's borders. ${ }^{37}$ As this study seeks to determine whether the meaning of the term 'non-international armed conflict' within the context of Common Article 3 indeed includes a geographic restriction, these terms will be used as follows: First, the term 'civil war' is employed when referring to such situations occurring prior to and at the time of the drafting of the Geneva Conventions as this was the terminology used at this time, as reflected in the drafting history. ${ }^{38}$ Further, as a legal construct the term 'war' has fallen into disuse and has been replaced with the term 'armed conflict'. ${ }^{39}$ The term 'internal armed conflict' thus is used to refer to contemporary 'civil war', essentially non-international armed conflicts confined to the territory of a single state. ${ }^{40}$ Finally, the term 'non-international armed conflict' is regarded by the author as synonymous with the usages 'civil war' and 'internal armed conflict'. However, this meaning is under pressure to be extended to other types of conflict not fitting the mould of either non-international or international armed conflict, and in this article its meaning is questioned. ${ }^{41}$ It is for this reason that the term 'non-international armed conflict'

352016 ICRC Commentaries, above n. 9, para. 105. '[T] 2 raditionally non-international armed conflicts have predominantly been understood as armed conflicts against or between non-state armed groups within the confines of a state, in the sense of an "internal" armed conflict. However, that raises the question of whether the limitation to the territory of one state is a requirement for a non-international armed conflict in the sense of Common Article 3.'

$36 \quad$ Geneva Conventions, above n. 11.

$37 \quad$ See Sects. 2 and 3.1 of this article.

$38 \quad$ Final Record, above n. 15.

39 See Mikos-Skuza (2012), p. 19.

402016 ICRC Commentaries, above n. 9, paras. 105 and 115.

$41 \quad$ See Sects. 2 and 3 of this article. 
is employed as an umbrella term referring to those types of conflicts in which only one party is a state actor, and the other parties are non-state actors, regardless of the geographic footprint of the conflict. This section now proceeds with an examination of the traditional interpretation of Common Article 3.

The introductory lines of Common Article 3 imply that there is a geographical requirement to the wording 'armed conflict not of an international character' by including the phrase 'occurring in the territory of one of the High Contracting Parties' ${ }^{42}$ The term 'High Contracting Parties' refers to signatory states to the Geneva Conventions. The term 'territory' suggests that 'an armed conflict not of an international character' should take place within the boundaries of the territory of a signatory state. ${ }^{43} \mathrm{In}$ accordance with the broadly-accepted notion of 'territory' in public international law, this spatial dimension of statehood includes land areas; $;{ }^{44}$ subsoil $;{ }^{45}$ airspace $;{ }^{46}$ internal waters $;{ }^{47}$ and its territorial seas. ${ }^{48}$ The concept of territory also 'includes islands, islets, rocks, and reefs' ${ }^{49}$ Such territories are delineated by boundaries that need not, however, be fully defined. ${ }^{50}$ It is important to note that under international law there is no requirement which determines that a territory has to be geographically indivisible and be contiguous, ${ }^{51}$ neither is there a rule stating the minimum size of the territory. ${ }^{52}$

It is important to note the inclusion of the term 'one' in the phrase 'occurring in the territory of one of the High Contracting Parties'. ${ }^{53}$ The Collins English Dictionary defines the adjective 'one' as 'single or lone'; 'only or unique'; 'distinct from'; and 'not two or more'. ${ }^{4}$ The inclusion of the term 'one' suggests that Common Article 3 does not apply to an armed conflict occurring on the territory of two or more High Contracting Parties, ${ }^{55}$ and limits the

\footnotetext{
42 Geneva Conventions, above n. 11.

43 Ibid.

$44 \quad$ Shaw (1982), p. 66. Land is understood as land permanently above the low-water mark.

45 Brownlie (2008), p. 115. Territorial subsoil refers to the subsoil adjacent to the land belonging to the sovereign state.
}

$46 \quad$ Brownlie (2008), p. 115; Boothby (2012), p. 328; Giemulla and Weber (2011), p. 6. When examining the term 'airspace', it is important to note that airspace extends both horizontally and vertically. International law has failed to provide a binding definition of the term 'airspace'. Its vertical dimension, nevertheless, has traditionally been set at between 80 to 120 kilometres above the earth's surface. The Karman line, which establishes the boundary between the earth's atmosphere and outer space at 100km above sea level, also enjoys wide acceptance. The horizontal dimension refers to the state's sovereign borders. This horizontal dimension of airspace refers to airspace adjacent to the land territory of the state and its internal water and territorial seas form part of the territory of the state.

$47 \quad$ Brownlie (2008), p. 116. The legal concept 'internal waters' includes lakes and rivers included in the land territory of a state. Water on the landward side of baselines from which the territorial sea is considered internal water.

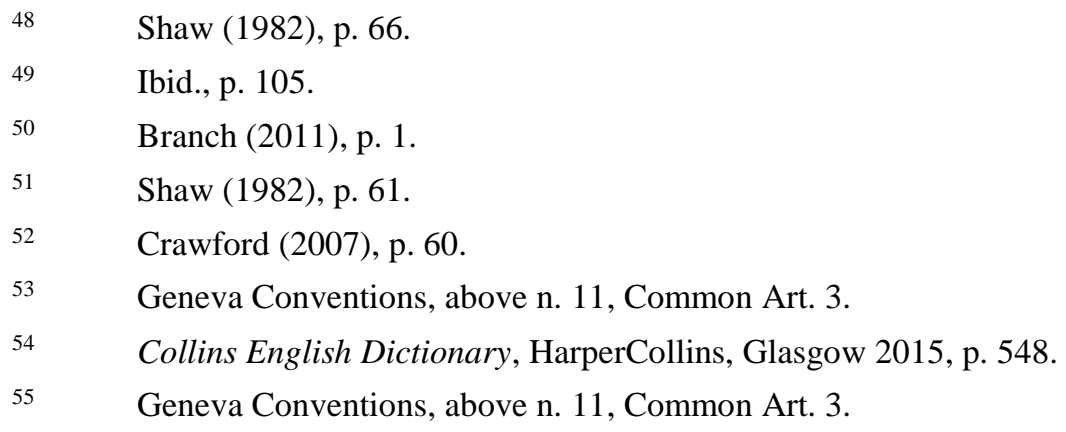


application of Common Article 3 to within the confines of the borders of a single High Contracting Party. The wording 'not of an international character' supports this interpretation. The adjective 'international' is defined as two or more states, ${ }^{56}$ whereas 'not' negates the meaning of the term 'international' to mean 'domestic'. ${ }^{57}$ A conflict not of an international character is a domestic armed conflict: a conflict in which only one state is involved. A literal reading of the meaning of the phrase 'occurring in the territory of one of the High Contracting Parties', interpreted in relation to the phrase 'armed conflict not of an international character', therefore, can reasonably be construed to confirm the existence of a geographical requirement determining that such a non-international armed conflict should take place within the borders of a single state. ${ }^{58}$

The drafting history of Common Article 3 confirms this interpretation. Little mention is made of the geographic requirement in the records reflecting the drafting history. ${ }^{59}$ It may be argued that this absence is indicative of the fact that the inclusion of the geographic requirement was not contentious. ${ }^{60}$ The drafting history, however, does reveal the intent of the drafters to regulate only situations of traditional civil war. ${ }^{61}$ It further defines the understanding of the term 'civil war', at the time of drafting, as a conflict between a state and a non-state actor or multiple non-state actors which takes place within the territory of a single state. ${ }^{62}$ The counter-argument to this reading involves attaching more weight to the 'possible' intention of the drafters for Common Article 3 to apply as widely as possible, as nowhere in the drafting history is it clarified whether the drafters meant that such wide application entailed a cross-border application or the application of Common Article 3 to situations other than those classed as belligerency. ${ }^{63}$ This counter-argument does not adequately consider the references to civil war in its construction. ${ }^{64}$

The evolutive approach followed by the European Court of Human Rights in its interpretation of the European Convention of Human Rights ${ }^{65}$ places greater importance on the theory that a treaty is a living instrument than it does on the intention of the drafters of the instrument. ${ }^{66}$ Essentially, the European Court of Human Rights considers the European

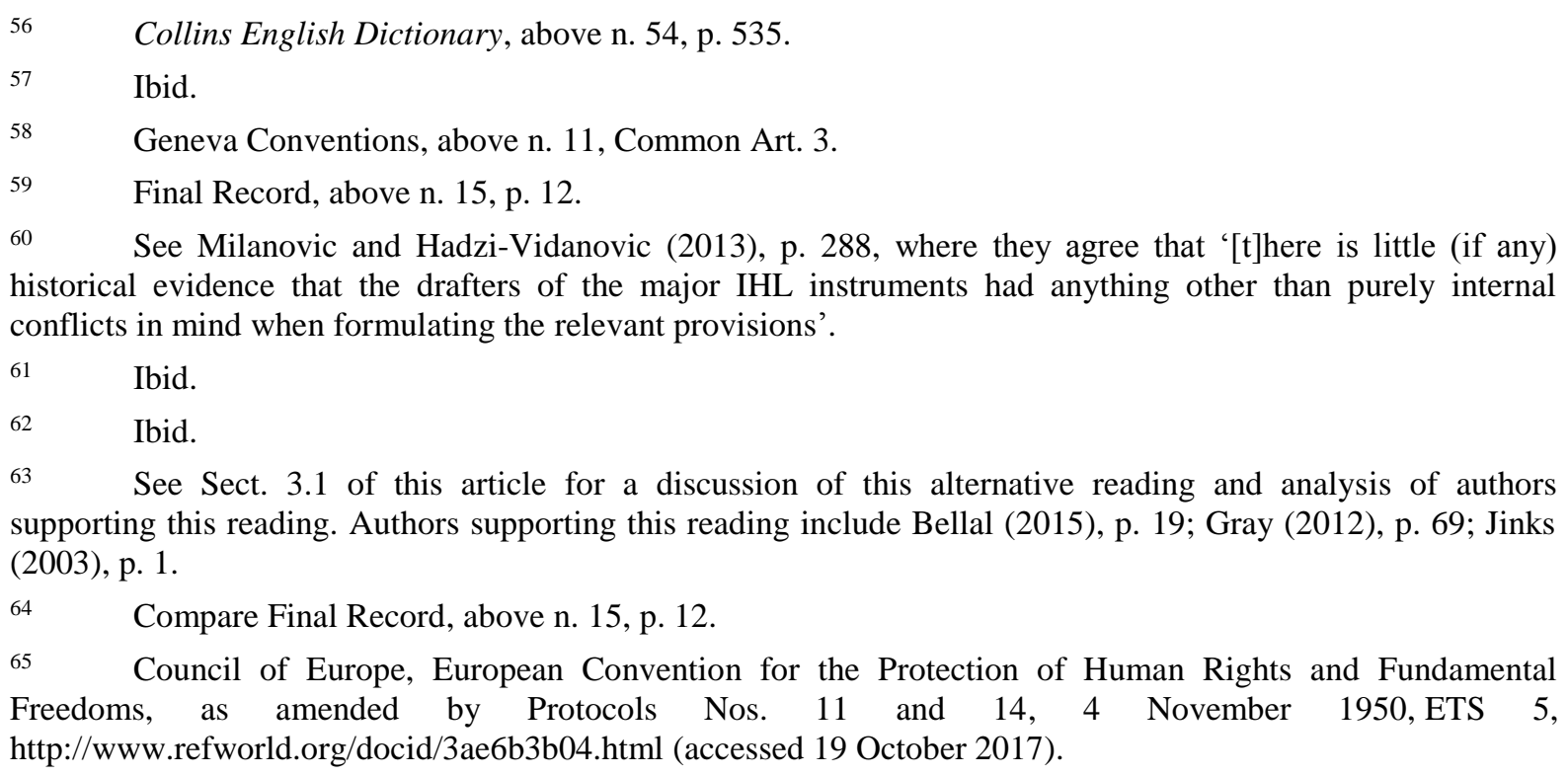

$66 \quad$ See Viljanen (2015); See also Tyrer v. The United Kingdom, Appl. No. 5856/72, ECtHR, 15 March 1978, http://www.refworld.org/cases,ECHR,402a2cae4.html (accessed 19 October 2017); Letsas (2010), pp. 518, 527; Matthews v. United Kingdom, Appl. No. 24833/94, 30 EHRR (1999) 361, para. 39; see discussion of 
Convention of Human Rights to be a 'living instrument' rather than a static one, which should reflect social changes and contemporary values. ${ }^{67}$ In essence, the consequence is that present-day human rights standards trump the intention of the drafters of a treaty as reflected in the drafting history. ${ }^{68}$ However, this view is contrary to Article 32 of the Vienna Convention on the Law of Treaties.

Although the author is aware of both the value and the pitfalls in such an interpretation, this is not the focus of the article. However, attention needs to be paid to the question whether or not an 'evolutive interpretation' of Common Article 3 has the consequence of minimising or ignoring the drafting history, which clearly limits the scope of application of Common Article 3 to internal armed conflicts and instead supports a wider reading. ${ }^{69}$ The result would be to extend the scope of application of Common Article 3 beyond the borders of a single state party to the Geneva Conventions. There is an identifiable restriction which limits the reach of this 'evolutive theory' approach as it is practised by the European Court of Human Rights. ${ }^{70}$ That is that the European Court of Human Rights needs to establish shared and commonly-accepted standards amongst its contracting states, with the exception that a moral reading is the seminal approach. ${ }^{71}$

A survey of subsequent practice reveals that it has not commonly been agreed that the standards enshrined in Common Article 3 should apply to conflicts other than internal conflicts. $^{72}$ Furthermore, the European Court of Human Rights employs this 'living instrument' approach in giving content to the rights it serves to protect, and not to expand the scope of application of the treaty. ${ }^{73}$ The Geneva Conventions fall within the body of international humanitarian treaty law and not international human rights law, which is the case for the European Convention on Human Rights. The case law of the European Convention on Human Rights differentiates between a human rights law regime and international humanitarian law as these are areas of law which serve different purposes. ${ }^{74}$ Finally, the strongest argument in support of the view that the rules of interpretation as codified in the Vienna Convention should regulate the interpretation of the scope of application of Common Article 3 is that the contracting states to the European Convention on Human rights permit the court such wide jurisdiction, as one scholar puts it, in order 'to protect whatever human rights people in fact have and not what human rights domestic

\footnotetext{
\begin{tabular}{llllllll}
\hline Marckx $\quad$ v. Belgium, & Appl. $\quad$ No. $\quad 6833 / 74$, & ECtHR, & 13 & June & 1979 ,
\end{tabular} http://www.refworld.org/cases,ECHR,3ae6b7014.html (accessed 19 October 2017). In: Letsas (2010), pp. 529530.

$67 \quad$ Viljanen (2015); Letsas (2010), pp. 513, 518.

68 Letsas (2010), pp. 513, 518, 540.

69 Ibid.

$70 \quad$ See Viljanen (2015); cf Letsas (2010), pp. 527-528.

$71 \quad$ Letsas (2010), pp. 532, 538; Letsas (2013), p. 107.

72 See discussion in Sect. 3.2 of this article.

73 Cf. Letsas (2010), pp. 509-541.

74 See Jaloud v. The Netherlands, Appl. No. 47708/08, ECtHR, 20 November 2014; Al-Jedda v. United Kingdom, Appl. No. 27021/08, ECtHR, 7 July 2011; Hassan v. United Kingdom, Appl. No. 29750/09 (2014). For a discussion of the interpretive approach followed by the European Court of Human Rights, see Honko (2016); Hailbronner (2016), pp. 339-364.
} 
authorities or public opinion think people have'. ${ }^{75}$ The state parties to the Geneva Conventions have not encouraged or permitted the adoption of a similar approach. Therefore, the law of treaty interpretation prevails and the importance of the drafting history of Common Article 3 remains a relevant tool of interpretation.

An examination of the object and purpose of Common Article 3 does not offer any arguments against its traditional interpretation. In this context, the Preambles of the four Geneva Conventions do not reveal much: They are aimed at the regulation and protection of the wounded and sick among the armed forces in the field; the wounded, sick and shipwrecked of the armed forces at sea; prisoners of war; and civilians during international armed conflict. ${ }^{76}$ Additional Protocol II may be used to interpret Common Article 3. It regards a non-international armed conflict as one occurring within the boundaries of a single state. $^{77}$

Article 31(3)(a) of the Vienna Convention on the Law of Treaties ${ }^{78}$ regards a subsequent agreement between parties as a further avenue that may be explored to aid the interpretation process. ${ }^{79}$ Protocol II Additional to the Geneva Conventions (Additional Protocol II) serves to supplement and develop the regime codified in Common Article $3 .^{80}$ The title 'Protocol Additional to the 1949 Geneva Conventions', ${ }^{81}$ read together with the Preamble ${ }^{82}$ and Article 1(1) of Additional Protocol II, ${ }^{83}$ is of significance for this analysis. Not only does such a reading confirm the relationship between Common Article 3 and Additional Protocol II, as well as the object and purpose of Additional Protocol II, but it reads that Additional Protocol II specifically binds only signatories to Additional Protocol II. Not all states party to the four Geneva Conventions, however, are also signatories to Additional Protocol II. The question thus arises of whether an Article 31(3)(a) approach to treaty interpretation will remain valid. Article 31(3)(a) explicitly refers to 'subsequent agreements between parties'. This raises the question of whether only subsequent agreements which all

\footnotetext{
$75 \quad$ Letsas (2013), p. 118, fn. 60.

76 Geneva Conventions, above n. 11.

771977 Geneva Protocol II Additional to the Geneva Conventions of 12 August 1949, and Relating to the Protection of Victims of Non-International Armed Conflict, 1125 UNTS 609, Art. 1(2).

78 Vienna Convention, above n. 30.

79 Ibid., Art. 31(3)(a).

$80 \quad$ Protocol II, above n. 77, Art. 1(1). 'This Protocol, which develops and supplements Article 3 common to the Geneva Conventions of 12 August 1949 [...] [emphasis added]'. For a discussion of the drafting history of Additional Protocol II as well as an analysis of its content, see Moir (2003), pp. 89-132; Zegveld (2002), pp. 9-34. See Cassese (1981), p. 416.

81 Emphasis added.

$82 \quad$ Additional Protocol II, above n. 77, Preamble.

83 Additional Protocol II, above n. 77. 'This Protocol, which develops and supplements Article 3 common to the Geneva Conventions of 12 August 1949 without modifying its existing conditions of application, shall apply to all armed conflicts which are not covered by Article 1 of the Protocol Additional to the Geneva Conventions of 12 August 1949, and relating to the Protection of Victims of International Armed Conflicts (Protocol I) and which take place in the territory of a High Contracting Party between its armed forces and dissident armed forces or other organized armed groups which, under responsible command, exercise such control over a part of this territory as to enable them to carry out sustained and concerted military operations and to implement this Protocol [emphasis added]'.
} 
parties to the previous conventions ratify are intended to be applicable under this provision. ${ }^{84}$ Such an interpretation excludes an analysis of Additional Protocol II. Therefore, the question arises as to whether Additional Protocol II can be useful in the process of interpreting Common Article 3 where parties to the two treaties do not completely overlap. At the very least, the interpretative role of Article 1(1) would apply in those cases where the parties to the Geneva Conventions and Additional Protocol II do overlap. So, at least for those states, it would make sense to interpret Common Article 3 in light of Additional Protocol II.

This traditional interpretation of the geographical requirement as being inherent in Common Article 3 from the time of its adoption initially received hardly any attention by both states and scholars. For example, the 1952 Commentaries to the Geneva Conventions did not debate the term 'conflict not of an international character' and failed to give any special attention to the geographic requirement. ${ }^{85}$ The traditional interpretation of the geographic scope nonetheless was reflected in customary international law at the time of the drafting of the Rome Statute. ${ }^{86}$ It has been argued that the Rome Statute is reflective of the customary definition of a non-international armed conflict and that it defines these conflicts as "conflicts which take place in the territory of a state when there is protracted armed conflict between governmental authorities and organized armed groups or between such groups ${ }^{87}$ The San Remo NIAC Manual also understands a non-international armed conflict to be confined to the territory of a single state, and expressly states that non-international armed conflicts do not encompass conflicts extending to multiple states. ${ }^{88}$

In summary, the traditional reading limits the application of Common Article 3 to apply only within the territory of a state party to the Geneva Conventions; a contemporary reading, which is supported by the ICRC, allows for a broader application of this provision. The conventional understanding of the wording 'armed conflict not of an international character', interpreted together with 'occurring in the territory of one of the High Contracting Parties', as contained in the text of Common Article 3, supports the notion that a geographical requirement is applicable to this provision. ${ }^{89}$ It is arguable that this geographical requirement limits the application of Common Article 3 to those armed conflicts "not of an international character' which occur within the borders of a single High Contracting Party to the Geneva Conventions. These types of conflict are known either as intra-state international armed conflicts or as internal armed conflicts. ${ }^{90}$

$84 \quad$ Vienna Convention, above n. 30, Art. 31(3)(a): 'There shall be taken into account, together with the context: (a) any subsequent agreement between the parties regarding the interpretation of the treaty or the applications of its provisions [...] [emphasis added]'.

852016 ICRC Commentaries, above n. 9.

$86 \quad$ Nicaragua, above n. 13, p. 114; Cullen (2004), p. 193.

871998 The Rome Statute of the International Criminal Court, 2187 UNTS 90, Art. 8(2)(f) (emphasis added).

$88 \quad$ Schmitt, Garraway and Dinstein (2006), para. 1.1.

89 For scholarship supporting this interpretation, see Schmitt, Garraway and Dinstein (2006); Paust (2016), p. 46; The Joint Service Manual of the Law of Armed Conflict (United Kingdom), Joint Service Publication 383, 2004 edn., paras. 3.6 and 15.3; Australian Defence Doctrine: Law of Armed Conflict, The Executive Series ADDP 06.4 (2006), para. 1.52.

$90 \quad$ Schondorf (2004), p. 3; Corn and Jensen (2000), p. 56. 


\section{Alternative Reading Supported by the ICRC}

Recently some states, ${ }^{91}$ scholars and the ICRC have supported the view that Common Article 3 does not dictate a clear geographical requirement and, therefore, that Common Article 3 applies to 'spill-over', 'cross-border' and 'transnational' armed conflicts. ${ }^{92}$ This line of reasoning argues that the legally-recognised categories of armed conflicts are changing and that these 'other' situations, such as 'cross-border' armed conflicts, 'spill-over' armed conflicts and 'transnational' armed conflicts, fall within the scope of application of Common Article $3 .{ }^{93}$

\subsection{Contemporary Interpretation}

The 2016 ICRC Commentaries challenge the status quo and put forward the argument that a conflict between an organised armed group and a state, or between two or more organised armed groups, will be regarded as a conflict within the scope of application of Common Article 3 even if the fighting crosses borders or occurs within the borders of multiple territories:

[A]nother reading could put the emphasis on the fact that the conflict must occur in the territory of one of the 'High Contracting Parties', thereby merely excluding conflicts which occur on the territory of a State not party to the Geneva Conventions. Common Article 2 likewise contains a reference to the States party to the Geneva Conventions. Viewed in this context, the reference to High Contracting Parties in both articles may have been included to avoid any misunderstanding to the effect that the 1949 Geneva Conventions would create new obligations for States not party to them. ${ }^{94}$

According to this view, the only requirement is that the territory or territories in which fighting takes place must belong to signatories of Common Article $3 .{ }^{95}$ As the Geneva Conventions have been universally ratified, the practical implication is that there is no geographical limitation inherent to Common Article $3 .{ }^{96}$ Consequently, this could mean that 'transnational' armed conflicts, 'spill-over' conflicts and 'cross-border' armed conflicts could be considered 'armed conflicts not of an international character' in the meaning of Common Article 3 if the fighting occurs in the territory of a High Contracting Party to the Geneva Conventions.

The main policy consideration prompting this alternative reading is that, since 9/11, there arguably has been more awareness of these different types of armed conflict that are

\footnotetext{
91 These states include the United States of America, Indonesia and France; see discussion at Sect. 3.2.1.

922016 ICRC Commentaries, above n. 9, paras. 102-132. See ICRC Opinion Paper, above n. 28, p. 5; Corn and Jensen (2000), p. 48, 69; Milanovic and Hadzi-Vidanovic (2013); Vite (2000), p. 69; Cullen (2004), p. 189; Kretzmer (2005), p. 171; Jinks (2003), p. 1; Schondorf (2004); Daskal (2013), p. 1165; Schoberl (2015).

93 Ibid.

2016 ICRC Commentaries, above n. 9, para. 116.

95 Schoberl (2015), p. 78; Schmitt (2014), p. 12; ICRC Opinion Paper, above n. 28, p. 5.

96 Compare Corn and Jensen (2000), p. 56.
} 
increasingly being recognised. These armed conflicts are non-international armed conflicts that originated as internal armed conflicts but have crossed sovereign borders into foreign territory, or territories, as the fighting progressed. Currently, there are examples of armed conflicts which do not fit the Common Article 3 mould, such as the conflict in Syria involving the Islamic State (IS) which spills over into Iraqi territory $;^{97}$ the ongoing conflict between Hezbollah and Israel where the conflict crosses into Lebanese territory; ${ }^{98}$ and the conflict between the United States and Al Qaida and the Taliban in Afghanistan. ${ }^{99}$

As illustrated in section two, the traditional interpretation of Common Article 3 excludes such conflict situations from its scope of application. The ICRC deems it illogical that the protection offered by Common Article 3 should end at the border of a single High Contracting Party in the event of the violence spreading to multiple territories. ${ }^{100}$ Scholarly opinion shares this sentiment, namely, that it does not make sense that 'victims of conflicts spilling over the territory of several states should benefit from less protection than those affected by conflicts limited to the territory of only one state'. ${ }^{101}$ Other scholars acknowledge the fact that, whereas domestic law could offer a partial solution to this legal void, its application does not overcome the moral dilemma that the non-application of Common Article 3 could create. ${ }^{102}$ They raise as an example rape which, if committed on one side of the border, constitutes a war crime but not on the other side of the border not regulated by Common Article 3. ${ }^{103}$

There is value in the argument that the law of non-international armed conflict needs to be adjusted in order to regulate such conflict situations so as to provide a regulatory framework under international humanitarian law. However, international humanitarian treaty law, specifically Common Article 3, might not demonstrate that reach and is limited to the confines of the borders of a single High Contracting Party as per its traditional understanding. The ICRC's consideration that it is illogical that protection should cease at a border is in line with the view of the Pictet commentaries that Common Article 3 should apply as widely as possible, ${ }^{104}$ but that it is a policy consideration and not a question of law: Whether or not the law should be extended is a separate question to the question of what the law is at this point in time.

This alternative reading of Common Article 3 by the ICRC is supported by scholars who consider the 'gap theory' to be instructive in such a situation. ${ }^{105}$ Their concern is that if the protection of Common Article 3 were limited to internal armed conflicts, then protection

\footnotetext{
$97 \quad$ Haque (2016); Arimatsu and Choudhury (2014), p. 1.

$98 \quad$ Kress (2012), p. 165; Schondorf (2004), p. 36; Schoberl (2015), p. 69.

$99 \quad$ See Kress (2012); Brooks (2004), p. 675; Schoberl (2015) p. 69; Jinks (2003). This conflict, however, originated as an international armed conflict which began shortly after $9 / 11$ and has evolved into a noninternational armed conflict fought on both the territory of Afghanistan and the bordering mountainous regions of Pakistan.

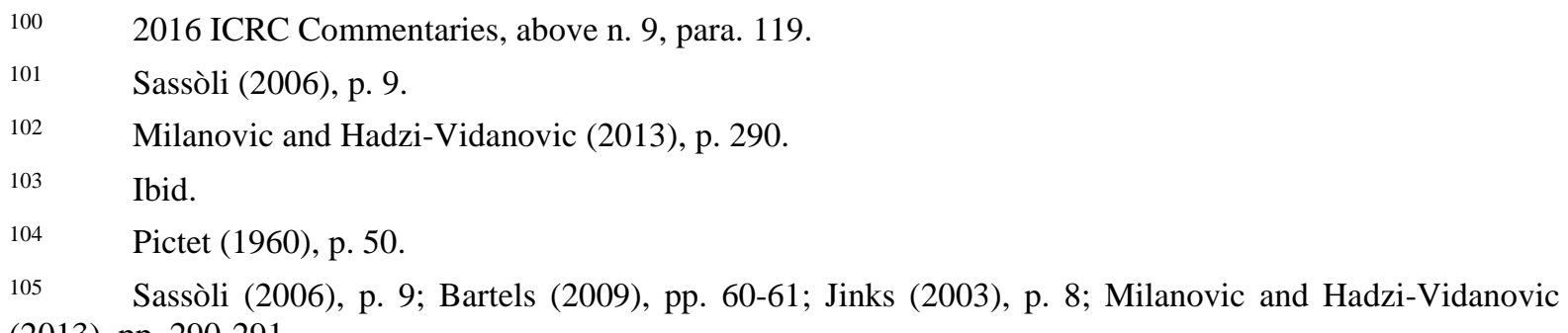
(2013), pp. 290-291. 
is not afforded to victims or fighters on the other side of the border, resulting in a lacuna as far as protection is concerned. ${ }^{106} \mathrm{~A}$ doctrinal approach designed to overcome this 'gap' reads the text 'occurring in the territory of one of the High Contracting Parties' differently from the traditional interpretation and the drafting history. ${ }^{107}$ It is suggested in this reading that one of the High Contracting Parties merely necessitates a jurisdictional link between the 'second or other' territory and Common Article 3 to satisfy the territorial requirement, ${ }^{108}$ which link is fulfilled if a conflict 'spills over' or crosses from the territory of a High Contracting Party into the territory of a second or other state (which is also a signatory to the Geneva Conventions). ${ }^{109}$ According to this line of thinking, the construct 'territory of one of the High Contracting Parties' is interpreted to mean that the armed conflict not of an international character is regulated by Common Article 3 if it does not cross into the territory of a nonstate party to the Geneva Conventions. ${ }^{110}$

The customary international law status of Common Article 3 is not sufficient to overcome this 'gap'. ${ }^{111}$ Under customary international law, the scope of application of Common Article 3 is limited to the borders of a single state if it is interpreted that a territorial clause indeed is included in the construct 'armed conflict not of an international character'. ${ }^{112}$ At this stage, customary international law has not evolved to extend the scope of application beyond internal armed conflict, a view which is supported by the fact that the relevant war crime provisions of the Rome Statute, which are considered to reflect customary international law, consider a Common Article 3-type armed conflict to be limited to the territory of a single state. ${ }^{113}$ The United States experience post-9/11 probes the question whether the norms

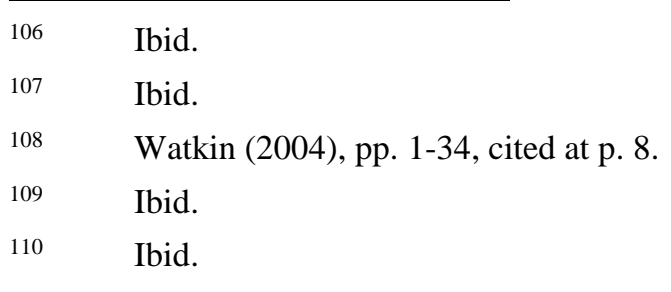

111 See Pejic (2011), p. 203 who summarises the 'gap theory': 'Despite the customary nature of the substantive provisions of Common Article 3, its territorial clause has given rise to what may be called the 'gap theory'. According to proponents of this view, because there are no IHL treaty rules applicable to an armed conflict involving states and non-state armed groups with extraterritorial effect, such a conflict is either governed only by customary law, including Common Article 3; or would require the development of a new legal framework.'

112 Ibid.

113 Art. 8(2)(d) of the Rome Statute, above n. 87, determines that the International Criminal Court may exercise jurisdiction over the crimes listed in Art. 8(2)(c) of the Statute if such alleged war crimes have been committed in the context of an armed conflict not of an international character. The logical deduction from the inclusion of the phrase 'armed conflict not of an international character' in this provision is that it mimics the scope of application of Common Art. 3 determining that a Common Art. 3-type armed conflict should be in existence for Common Art. 3-type war crimes to be committed. Thus, if the scope of application is that of a Common Art. 3-type armed conflict, then the content of the term 'organised armed group' will be identical for both Common Art. 3 and Art. 8(2)(d) of the Rome Statute. Furthermore, the war crime provisions of the Rome Statute are said to be reflective of customary international law. United Nations Diplomatic Conference of Plenipotentiaries on the Rome on the Establishment of an International Criminal Court, 15 June-17 July 1998: Vol. II Summary Records of the Plenary Meetings and of the Meetings of the Committee of the Whole, 247, paras. 108, 294; para. 102-12, 169; para. 41, 277; para. 44, 67; paras. 76, 161. See also Cullen (2004), pp. 193, 208; Art. 8(2)(f) of the Rome Statute determines the scope of a non-international armed conflict to be formulated as 'armed conflicts not of an international character and thus does not apply to situations of internal disturbances and tensions, such as riots, isolated and sporadic acts of violence or other acts of a similar nature. It 
included in Common Article 3 truly are sufficient to regulate extraterritorial armed conflict: ${ }^{114}$ Will stretching its application be sufficient to address the demands of these types of non-international armed conflict, ${ }^{115}$ and does the extraterritorial application of Common Article 3 sufficiently address this lacuna? ${ }^{116}$ It has been argued that it should be acknowledged that there is a gap in regulation; that the Geneva Conventions do not apply and that the focus should be on determining the applicable legal framework for situations that fall under this 'gap'. ${ }^{117}$ Various commentators have recognised this need for regulation. ${ }^{18}$

The ICRC's alternative reading of the text is open to a number of objections. The 2016 ICRC Commentaries argue that the drafting history of Common Article 3 allows for a broader interpretation of Common Article 3 by highlighting, during the negotiation around Common Article 3, the fact that a draft of this provision was considered which read 'which may occur in the territory of one or more of the High Contracting parties'. ${ }^{119}$ The phrase 'or more' was excluded from the final draft and was not adopted by the Diplomatic Conference. ${ }^{120}$ The 2016 ICRC Commentaries suggest that the exclusion of the phrase 'one or more' and the lack of discussion about its deletion do not have consequences for the interpretation of the text. On the contrary, the fact that the words 'of one or more' were excluded and, subsequently, were explicitly deleted from the text, arguably equally reveals that it was purposefully decided to exclude these words. By the same token, it is fair to contemplate that the lack of discussion concerning the deletion of the phrase 'one or more' indicates that states agreed that the situations intended to be regulated by Common Article 3 were occurrences of civil war within the borders of a single state. The 2016 ICRC Commentary is fairly selective as it does not acknowledge other parts of the drafting history which reveal the intent of the drafters to regulate only traditional situations of civil war, and that such conflict takes place within the territory of a single state. ${ }^{121}$ The significance of the deletion of the phrase 'or more' is diminished by the reality that inferences could be drawn to support both the broader ICRC interpretation as well as the restricted traditional view

applies to armed conflicts that take place in the territory of a State when there is protracted armed conflict between governmental authorities and organized armed groups or between such groups [emphasis added]'. It refers to the territory of a state and not to multiple states. Pejic agrees that a wide interpretation of the territorial clause of Common Art. 3 is not at present reflective of customary international law. Pejic (2011), p. 204.

114 Bellinger III and Padmanabhan (2011), pp. 201-243 and John B. Bellinger, Lecture at the University of Oxford, Oxford, England, 10 December 2007, Oxford Leverhulme Programme on the Changing Character of War transcript, https://2001-2009.state.gov/s/1/2007/112723.htm (accessed 23 October 2017).

115 Ibid.

116 Ibid

117 Pejic (2011), p. 204, fn. 47. Some also acknowledge that there are certain shortcomings inherent in Common Art. 3 and that a special legal regime is needed to regulate these new types of non-international armed conflict. See Bellinger, above n. 115; Bellinger and Padmanabhan (2011). See also Corn (2007), fnn. 80-82.

118 Pejic (2011), p. 202, fn. 41, citing Kretzmer: 'There is no substantive reason why the norms that apply to an armed conflict between a state and an organized armed group within its territory should not also apply to an armed conflict with such a group which is not restricted to its territory. It therefore seems [...] that to the extent that treaty provisions relating to non-international armed conflicts incorporate standards of customary international law, these standards should apply to all armed conflicts between a state and non-state actors. This means that, at the very least, Common Article 3 will apply to such conflicts.' See also Corn (2007), fnn. 80-82.

1192016 ICRC Commentaries, above n. 9, paras. 116, 119.

120 Ibid.

121 Cf. Final Records, above n. 15, p. 71 and 2016 ICRC Commentaries, above n. 9, para. 119. 
confining the application of Common Article 3 to the borders of a single state. None of these readings can irrefutably be substantiated by authority.

The ICRC further supports this alternative reading through a contextual interpretation of the text. ${ }^{122}$ It argues that the object and purpose of Common Article 3 aims at providing a certain minimum protection for civilians or persons no longer taking part in hostilities during armed confrontations between states and non-state actors. ${ }^{123}$ This interpretation of the object and purpose of Common Article 3 supports the notion that the type of actors involved in an armed conflict is a determining factor in the categorisation of an armed conflict and that no implied geographic limitation exists. This interpretation seems novel. Part (a) of Common Article 3 aims at protecting persons not actively taking part in hostilities, but one cannot read this provision in isolation. As mentioned above, the scope of application of Common Article 3 is determined by the opening lines of this provision. The wording 'which may occur in the territory of one or more of the High Contracting Parties' cannot be ignored. ${ }^{124}$

Such an approach nevertheless is supported by proponents of the 'gap theory' who encourage a wider interpretation of Common Article 3 to overcome a lacuna in the law of non-international armed conflict concerning the regulation of non-international armed conflicts other than internal armed conflicts. ${ }^{125}$ These scholars are of the opinion that the existing law of non-international armed conflict, specifically Common Article 3, in itself is sufficient to regulate extra-territorial non-international armed conflicts and that the creation of new international humanitarian law is not necessary. ${ }^{126}$ The aim of treaty interpretation is to determine the legal obligation and scope of a treaty, and in the assessment of the law it does not allow a consideration of policy. ${ }^{127}$

The view of the ICRC relates to what the law ought to be, and although it reflects the doctrinal efforts by scholars to bridge lacunae in international law based on policy or on humane considerations, unfortunately these do not amount to binding international legal obligations. At first glance, the purposive approach of the ICRC, therefore, does not appear to take sufficient account of text, history and the pre-9/11 subsequent practice.

\subsection{Role of Subsequent Practice in Determining the Contemporary Interpretation}

Before coming to any definite conclusion about the ICRC's interpretation of the geographical scope of Common Article 3, one has to keep in mind that treaties are living instruments. This leaves open the possibility that subsequent practice may support a broader interpretation. ${ }^{128}$ Article 31(3) of the Vienna Convention determines that subsequent practice may be used as a

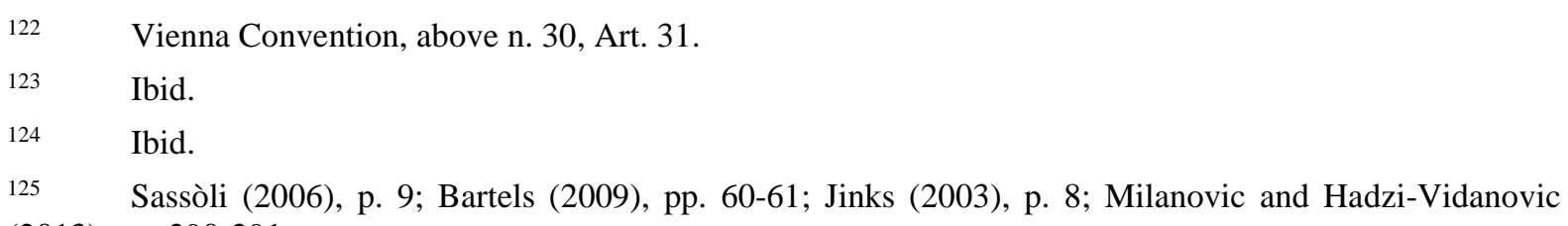
(2013), pp. 290-291.

126 Radin (2013), pp. 704-705; see fn. 30 where Radin cites the work of Sassòli and Sivakumaran, specifically Sassòli (2006) and Sivakumaran (2014), pp. 228-229. See contra Bellinger and Padmanabhan (2011), pp. 202-212 and Bellinger, above n. 115, who identify the shortfalls inherent in Common Art. 3 and call for a new treaty regime to regulate these extraterritorial types of non-international armed conflict.

127 Cf. Vienna Convention, above n. 30, Arts. 31 and 32.

128 For an overview on the law of subsequent practice, see Nolte (2013). 
tool of interpretation. ${ }^{129}$ Subsequent practice may be defined as the application of the treaty provisions by the signatories to such treaty. ${ }^{130}$ It becomes relevant to treaty interpretation if such practice concerning the interpretation of a treaty provision by member states of a treaty is endorsed by the agreement of the parties to the relevant treaty. ${ }^{131}$

This determination relates to the fact that treaties are considered to exist in an evolving context. ${ }^{132}$ International law provides for the continued validity of treaties, as these instruments (and specifically multilateral treaties) often need to be implemented over decades in an ever-changing world. International treaty law attempts to ensure the sustainability of multilateral treaties by acknowledging subsequent agreements and subsequent practice as forming part of the primary rules of treaty interpretation. ${ }^{133}$ Subsequent practice predominantly is employed as a tool of treaty interpretation after some time has elapsed since the conclusion of the treaty. The purpose is to verify whether the conduct of member states endorses the textual interpretation.

In order for subsequent practice to be used as an interpretative tool, such conduct must be uniform and be understood in the same way by the signatories to the relevant treaty. ${ }^{134}$ The text of Article 31(3)(c) of the Vienna Convention determines that for a practice to qualify as subsequent practice, such application of the treaty needs to establish 'the agreement of the parties regarding its interpretation'. ${ }^{135}$ Note that the word 'parties' is used in the plural but the word 'all' is not included. ${ }^{136}$ The ILC Study Group on subsequent agreements and subsequent practice in relation to the interpretation of treaties determines this to mean that subsequent practice is sufficient when the relevant evidence exists which proves that such conduct is 'concordant', 'consistent' and 'common'. ${ }^{137}$ Consequently, subsequent practice necessitates that parties conduct such practice wilfully and have an awareness of the consequences of their conduct in relation to the interpretation of the specific treaty provision. ${ }^{138}$ Therefore, the general understanding of Article 31(3)(c) is that the practice of a single state is hardly sufficient, ${ }^{139}$ which also is the case if several states to a multilateral treaty actively apply the provision in a broader context. ${ }^{140}$ The pattern of conduct of the

129 Vienna Convention, above n. 30. 'There shall be taken into account, together with the context (c) any subsequent practice in the application of the treaty which establishes the agreement of the parties regarding its interpretation.'

$130 \quad$ Nolte (2013), p. 309. "'Subsequent practice" covers any application of the treaty. It can also take various forms and may consist of action or inaction.'

$131 \quad$ Ibid., p. 173. '[S]ubsequent practice [...] constitutes objective evidence of the understanding of the parties as to the meaning of the treaty [...] [S] ubsequent practice only has this effect if it "shows the common understanding of the parties as to the meaning of the terms".'

132 Ibid., p. 3.

133 Ibid., p. 137.

134 Gardiner (2008), p. 227.

135 Vienna Convention, above n. 30.

136 See Nolte (2013), p. 17.

137 Ibid. 'Subsequent practice can be considered when the parties to a treaty, through their authorities, engage in common conduct, in the application of the treaty, and when such action is conducted wilfully and with awareness (belief, fully aware) of the consequences of their actions.'

138 Ibid.

139 Gardiner (2008), pp. 235-238.

140 Ibid. 
signatories to the treaty must convey that the concordant will of all parties can be established. ${ }^{141}$ Divergent practice, therefore, fails to reflect an agreement between parties. ${ }^{142}$

The outcome of employing subsequent practice potentially could be twofold: First, subsequent practice serves as a tool of treaty interpretation; ${ }^{143}$ second, subsequent practice may modify a treaty to the extent that it serves as a substitution for formal treaty modification. ${ }^{144}$ An example in this case would be that sufficient subsequent practice could effectively amend the text of Common Article 3 in order to broaden the scope of its geographical application. As a result, Common Article 3 would then also apply to noninternational armed conflicts other than internal armed conflicts. Subsequent practice as a means of interpretation thus serves to highlight openness to alternative or broader textual meanings. ${ }^{145}$ Therefore, through interpretation it can make treaties more adaptable to contemporary demands. As it is very difficult to amend multilateral treaties, subsequent practice may be necessary to facilitate the evolution of treaties in order for them to stay relevant, without the delay caused by the renegotiation of a treaty. Moreover, it is very challenging to clarify multilateral treaty provisions through the amendment of disputed provisions. It is further unlikely that multilateral treaties which are universally ratified, such as the Geneva Conventions, will ever be amended. Amendment through a different or broader interpretation of the text through subsequent practice may be the only realistic avenue to keep the Geneva Conventions relevant to contemporary armed conflict.

Some examples of scholarship and case law support the modification of treaties through subsequent practice. However, this position is contested. ${ }^{146}$ The third report of the ILC Study Group on subsequent agreements and subsequent practice in relation to the interpretation of treaties concluded that reported instances where subsequent agreements of treaty parties have led to modification of treaty provisions are rare. ${ }^{147}$ The report cautions that such an effect should not be presumed. ${ }^{148}$ Article 27(3) of the Charter of the United Nations (UN Charter) serves as such a rare example of modification through subsequent practice. ${ }^{149}$ The interpretation in practice of the term 'concurring votes', as included in Article 27(3) of the UN Charter in order to also include abstentions by the five permanent members, revealed that even when terms seem clear, the line between interpretation and modification of a treaty

\footnotetext{
$141 \quad$ Nolte (2013), pp. 112 and 215.

$142 \quad$ Ibid., p. 326.

143 Ibid., pp. 3, 21 and 170. '[T] he importance of such subsequent practice in the application of a treaty, as an element of interpretation, is obvious; for it constitutes objective evidence of the understanding of the parties as to the meaning of the treaty.'

$144 \quad$ Ibid., pp. 3, 21, 353. 'Finally, the role of subsequent practice is not only interpreting a treaty; certain decisions have found that the subsequent conduct of the parties had actually modified the treaty.'

145 Ibid., p. 181.

146 Ibid.

147 Ibid., p. 344.

$148 \quad$ Ibid.

149 Ibid., p. 181; 1945 Charter of the United Nations, [1945] ATS 1.
} 
provision may become blurred. ${ }^{150}$ This interpretation or, rather, modification, of Article 27(3) of the UN Charter was confirmed by the ICJ in the Namibia Advisory Opinion case. ${ }^{151}$

The most pertinent argument against treaty modification by means of subsequent practice is the inclusion of Article 41 of the Vienna Convention on the Law of Treaties, ${ }^{152}$ which regulates the modification of multilateral treaties. ${ }^{153}$ This provision makes no reference to subsequent practice as a possible avenue enabling treaty modification. ${ }^{154}$ It is also important to note that the scope of Article 41 is limited to agreements aimed at modifying multilateral treaties between certain parties only, not all the parties. ${ }^{155}$ This is permitted if the treaty which parties aim to modify does not forbid modification and if more protection is offered by the modification. ${ }^{156}$ The broadening of the scope of application of Common Article 3 arguably will fill a legal vacuum and will thus be permissible. ${ }^{157}$ The result of modification through Article 41 of the Vienna Convention on the Law of Treaties and modification as a result of treaty interpretation by employing Article 31(1)(3)(C) differs. ${ }^{158}$ Modification of a treaty provision through the application of Article 41 will apply only to certain parties, namely, the signatories to the modification agreement. ${ }^{159}$ On the other hand, the interpretation of a provision in accordance with Article 31(3)(c) may result in modification of the provision applicable to all signatories to the treaty if sufficient subsequent practice exists. ${ }^{160}$

It is unlikely that Article 41 of the Vienna Convention on the Law of Treaties has acquired customary international law status. ${ }^{161}$ The practical implication of the probable lack of customary status of Article 41 of the Vienna Convention is that it binds only member states to this treaty. Consequently, the possibility remains open of treaty modification through subsequent practice for non-signatory states to the Vienna Convention on the Law of Treaties. Article 4 of the Vienna Convention determines that the Convention may not be

$150 \quad$ Ibid. 'Decisions of the Security Council on all other matters shall be made by an affirmative vote of nine members including the concurring votes of the permanent members; provided that, in decisions under Chapter VI, and under paragraph 3 of Article 52, a party to a dispute shall abstain from voting.'

$151 \quad$ Legal Consequences for States of the Continued Presence of South Africa in Namibia (South-West Africa) Notwithstanding Security Council Resolution 276, Judgment of 21 June 1971, ICJ Reports 1971, p. 16.

152 Vienna Convention, above n. 30, Art. 41. '1. Two or more of the parties to a multilateral treaty may conclude an agreement to modify the treaty as between themselves alone if: (a) the possibility of such a modification is provided for by the treaty; or $(b)$ the modification in question is not prohibited by the treaty and: (i) does not affect the enjoyment by the other parties of their rights under the treaty or the performance of their obligations; (ii) does not relate to a provision, derogation from which is incompatible with the effective execution of the object and purpose of the treaty as a whole. 2. Unless in a case falling under paragraph 1(a) of the treaty otherwise provides, the parties in question shall notify the other parties of their intention to conclude the agreement and of the modification to the treaty for which it provides.'

153 Ibid.

$154 \quad$ Ibid.

155 Ibid.

156 Ibid.

$157 \quad$ See Sect. 2 of this article.

158 Compare Geneva Conventions, above n. 11, Art. 31(3)(c) and Vienna Convention, above n. 30, Art. 41.

159 For a discussion of Art. 41, see Dörr and Schmalenbach (2012), pp. 719-727.

160 Vienna Convention, above n. 30.

161 Dörr and Schmalenbach (2012), p. 722; contra Villiger (2009), p. 538. 
applied retroactively. ${ }^{162}$ The Vienna Convention was adopted in 1969 while the Geneva Conventions were adopted in 1949. ${ }^{163}$ The Geneva Conventions thus precede the Vienna Convention on the Law of Treaties by approximately 20 years. Article 41 of the Vienna Convention thus will only apply to the Geneva Conventions if it has indeed reached customary international law status. ${ }^{164}$ Therefore, if Article 41 has not attained customary international law status, which is the majority view, ${ }^{165}$ then Article 41 will not bar treaty modification through subsequent practice in respect of Common Article 3.

This argument raises the question as to what sources qualify as evidence of state practice. A consolidation of the work of the ILC Study Group on subsequent agreements and subsequent practice in relation to interpretation of treaties, ${ }^{166}$ the Second Report on Identification of Customary International Law, ${ }^{167}$ as well as ICJ jurisprudence, ${ }^{168}$ reveals a non-exhaustive list of the types of practice by states that are considered evidence of state practice. ${ }^{169}$ In the present context, the author deems state practice to be of particular significance in promoting an understanding of the status quo of the geographical requirement in Common Article 3 to include the physical actions of states, legislative acts, judgments of national courts and official publications in the relevant area of international law. These sources will be consulted in order to determine whether state practice between 1949 and the present is 'concordant', 'consistent' and 'common'. ${ }^{170}$ The existence of differing state practice counters the argument that the meaning of a provision has been altered in the context of Article 31(1) of the Vienna Convention on the Law of Treaties. Therefore, it will not be necessary to review the practice of all state parties to the Geneva Conventions, but a survey of some examples of such divergent state practice by a number of member states is deemed sufficient evidence that the traditional understanding of a provision continues and that the very high benchmark to advance a new understanding of the provision has not been met.

In the current context, the physical actions of states refer to the operational behaviour of the states' armed forces on the battlefield, for example, when the armed forces of the relevant state continue to comply with Common Article 3 when crossing into the territory of

162 Vienna Convention, above n. 30, Art. 4. 'Without prejudice to the application of any rules set forth in the present Convention to which treaties would be subject under international law independently of the Convention, the Convention applies only to treaties which are concluded by states after the entry into force of the present Convention with regard to states.'

163 Ibid.; Geneva Conventions, above n. 11.

164 See 2016 ICRC Commentaries, above n. 9, para. 3119 for a discussion of the relationship between the Vienna Convention on the Law of Treaties and the Geneva Conventions.

165 See n. 161.

166 Nolte (2013).

167 M. Wood, Third Report on Identification of Customary International Law, International Law Commission, Sixty-seventh session, 2015, A/CN.4/882.

168 Jurisdictional Immunities of the State (Germany v. Italy), Judgment of 3 February 2012, ICJ Reports 2012, p. 434, para. 55.

169 Physical actions of states; acts of the executive branch; diplomatic acts and correspondence; policy statements; legislative acts; opinions of government legal advisors; judgments of national courts; official publications in the relevant fields of international law; practice in connection with treaties; resolutions of organs of international organisations; practice of intergovernmental organisations; resolutions relating to legal questions raised in the General Assembly.

$170 \quad$ See note 136. 
a foreign state to continue their military operations that were initiated in their own territory. Legislative acts refer to military legislation (which forms part of the category of state practice, termed 'parliamentary practice') ${ }^{171}$ and draft bills and white papers (categorised as executive practice) ${ }^{172}$ aimed at regulating the conduct of the state's armed forces.

Official state publications relating to international humanitarian law, specifically military manuals, a source of executive practice, ${ }^{173}$ may be reflective of state practice. Reliance on military manuals, however, should be approached with caution, ${ }^{174}$ as it is contentious whether or not this is a valuable source of subsequent practice. ${ }^{175}$ First, it is necessary to promote a better understanding of this source. Different types of military manuals exist. ${ }^{176}$ For the purpose of this analysis, only national military manuals are considered. The purpose of these documents is two-fold. The practical purpose is to serve as a 'handbook' for practitioners dealing with the law of armed conflict and to disseminate the law. ${ }^{177}$ These national military manuals often are reduced to other publications directed at a target audience. ${ }^{178}$ For instance, such a manual not only lays down the framework within which military commanders can plan military operations, ${ }^{179}$ but a reduced version could also be used by soldiers on the ground. One example of this would be 'LOAC cards'. ${ }^{180}$ The second purpose they serve is that they have evidentiary value of the position or interpretation of the law adopted by the specific state. ${ }^{181}$

Prominent authors, ${ }^{182}$ international tribunals ${ }^{183}$ and the ICRC $^{184}$ itself have relied on this source as a form of state practice (in the context of customary international law).

\footnotetext{
$171 \quad$ Wood, above n. 167.

172 M. Wood, Fourth Report on Identification of Customary International Law, International Law Commission, Sixty-eight session, Geneva, 2016, A/CN.4/695, p. 21.

173 Wood, above n. 167.

$174 \quad$ For differing views concerning the use, purpose and value of military manuals, see Garraway (2004), p. 425; Garraway (2010), p. 45; Rogers (2010), p. 89; Turns (2010), p. 65; Von Heinegg (2010), p. 109; Reisman and Leitzau (1991), p. 1.

175 Ibid.

176 Garraway distinguishes between three different categories of military manuals. The first category is international manuals such as the 1913 Oxford Manual of Naval War. The second category is national military manuals which Garraway views as serving the purpose 'to lay out a national view of the legal constraints accepted by the particular state'. The third category is that of internal manuals which encapsulate instructions or regulations to its armed forces. Basically it is an audience-specific reduced version of the national manual. Garraway (2004), pp. 427-440.
}

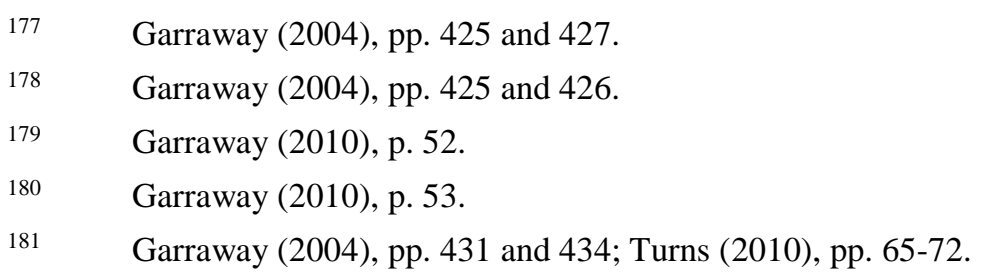

$182 \quad$ See Crawford (2012), p. 24; M. Wood, Second Report on Identification of Customary International Law International Law Commission, Sixty-sixth session, Geneva 5 May-6 June and 7 July-8 August 2014, General Assembly Report A/CN.4/672, paras. 40 and 41(f).

183 Garraway cites the example of the Čelebici case in which the ICTY Trial Chamber referenced two national military manuals in order to define command responsibility. See The Prosecutor v. Zejnil Delalić, Zdravko Mucić, Hazim Delić and Esad Landžo, ICTY Trial Chamber, Case No. IT-96-21-T, 16 November 1998 para. 358 as cited in Garraway (2004), p. 434, fn. 62. Turns cites the example of the Tadic decision where the Appeals Chamber expressly determined that 'military manuals are a useful tool in identifying military 
However, it may be argued that military manuals frequently outline what a state considers to be best practice rather than simply the minimum legal requirement. Therefore, they are not an entirely reliable source. This line of thinking should be approached with caution as national military manuals do not reflect the battlefield conduct of a state's armed forces, but rather propose what the conduct of armed forces should be in a specific situation. ${ }^{185}$ Even though this is true, the national military manual itself essentially still captures and reflects the official interpretation of existing humanitarian law in the form of a unilateral statement. ${ }^{186}$ Thus, it is the opinion of the author that, as these manuals reflect the interpretation by a state of the said provision, they remain an important tool in establishing how a provision is interpreted in the context of Article 31(3) of the Vienna Convention of the Law of Treaties.

\subsubsection{Executive Practice (Including Military Manuals)}

The 2015 Irish National Defence White Paper acknowledged the evolving nature of armed conflict. ${ }^{187}$ It considers a broad spectrum of actors to participate in armed conflict and follows a liberal approach towards the geographical element of armed conflicts. ${ }^{188}$ Similarly, the Indonesian Defence White Paper recognises that the legal construct 'armed conflict' is undergoing significant changes. ${ }^{189}$ The Indonesian Defence White Paper includes examples of spill-over armed conflicts and transnational armed conflicts, such as the armed conflicts in Syria, Afghanistan and Iraq, in its understanding of internal armed conflict, by implication extending the application of Common Article 3 to such conflicts. ${ }^{190}$

The 2015 United States Department of Defence Law of War Manual considers Common Article 3 to apply to 'states warring against non-state armed groups' which may be described as 'non-international armed conflicts', 'even if international borders are crossed in

operational practice and, therefore, state practice'. Prosecutor $v$. Duško Tadić aka 'Dule', Decision on the Defence Motion for Interlocutory Appeal on Jurisdiction, Case No. IT-94-1-A, A.Ch, 19 July 1998 para. 99, as cited in Turns (2010), p. 67.

184 Henckaerts and Doswald-Beck (2005) in which military manuals are frequently cited in footnotes as evidence of subsequent practice in international humanitarian law. For a discussion, see Garraway (2004), p. 434 and Turns (2010), pp. 66-67.

185 National Military Manuals on the Law of Armed Conflict, FICHL Publication Series No. 2 (2nd edn., 2010), p. 89; Turns (2010), p. 68.

186 Ibid.

187 White Paper on Defence, August 2015.

188 Ibid.

189 Defence Ministry of the Republic of Indonesia, Defence White Paper 2015.

190 Ibid. Executive practice which was consulted but did not comment on the geographic requirement under Common Art. 3 or did not include a definition of non-international armed conflict (or an armed conflict not of an international nature) includes that of the states of Armenia (FSC.EMI/179/15), Bosnia and Herzegovina (Law on Defence of Bosnia and Herzegovina, Official Gazette of Bosnia and Herzegovina, 88/ 05), the Netherlands (Netherlands Defence Doctrine), Denmark (Military Penal Code Act no. 530 of 24/06/2005), Estonia (Estonian Defence Forces Organisation Act, RT I 2008, 35, 213), India (D.O. No. 6(3)(58)/99-LC(LS), Namibia (Ministry of Defence: Defence Policy) and Nepal (Army Act, 2063 (2006)). The Netherlands in a policy decision applies international humanitarian law standards to all military operations, but this practice is not the result of a legal obligation. This practice is an example of an approach by which a regulatory gap can be overcome. See para. 3.2 of the Netherlands Defence Doctrine. 
the fighting'. ${ }^{191}$ The French Manuel du droit des conflict armés considers that a noninternational armed conflict, or an internal armed conflict, exists when prolonged armed violence occurs between governmental authorities and organised armed groups, or between such groups themselves, in the territory of one or several states. ${ }^{192}$ On the other hand, the 2004 Military Manual of the United Kingdom, ${ }^{193}$ the 2006 Military Manual of Australia ${ }^{194}$ and the South African National Defence Force: Joint Warfare Publication ${ }^{195}$ support the traditional definition of internal armed conflict. These examples serve as evidence that state practice is divergent. ${ }^{196}$

\subsubsection{Domestic Court Practice}

191 Department of Defence Law of War Manual, 12 June 2015 (United States of America), para. 3.3.1; contra Paust (2016), p. 46.

192 Manuel de droit des conflits armés (2012),

www.cicde.defense.gouv.fr/IMG/pdf/20130226_np_cicde_manuel-dca.pd (accessed 20 June 2017).

193 JSP 383: The Joint Service Manual of the Law of Armed Conflict, Joint Service Publication 383, 2004 edn., para. 15.3.

194 The Executive Series ADDP 06.4 Law of Armed Conflict (2006) Australian Defence Doctrine, para. 1.52 .

195 South African National Defence Force (Joint Operations Division): Joint Warfare Publication JWP 139 - African Battlespace (DS/OPS/DIV HQ/R/305/1P) (Access Restricted), para. 6. 'In the event of an armed conflict not of an international character (a civil war or other internal armed conflict), Common Article 3 to the 1949 Geneva Conventions will apply to the parties.'

196 Due to the author's limited knowledge of foreign languages and the restricted access to military manuals, only a select number of manuals could be consulted. These limitations do not compromise the results of this study or the value of the assessment of the available manuals, as subsequent practice requires the uniform interpretation by state parties. The fact that divergent interpretations exist is clearly reflected in the fact that the manuals of the United States (n. 192) and France (n. 193) support a broad interpretation of the scope of application of Common Art. 3, but which is contrary to the views in the manuals of the United Kingdom (note 194), Australia (n. 195) and South Africa (n. 196), which support the conventional reading of 'armed conflict not of an international character' and limit the scope of application of Common Art. 3 to internal armed conflicts alone. Military manuals of states which do not offer a definition of the scope of application of Common Art. 3 or of their understanding of a non-international armed conflict include those of Canada (B-GL-300-001/FP-001 Land Operations); Germany (ZDv 15/2 Humanitäres Völkerrecht in bewaffneten Konflikten-Handbuch, issued in August 1992.); New Zealand (Manual of Armed Forces LawL DM69 (2nd edn.) Vol 1); and the Philippines (Philippine Army Manual 1-10 (PAM 1-10) dated 21 May). The Canadian manual refers to Common Art. 3 in paras. 1702 and 1706, but does not offer any indication that it deviates from the traditional understanding of the article's scope of application. First, it does not specifically define 'non-international armed conflict' and, second, it quotes Common Art. 3 itself in its text. The author was able to access only the 1992 Military Manual of Germany which shows consistent support for the pre-9/11 interpretation that Common Art. 3 applies only to internal armed conflicts. It defines its understanding of non-international armed conflict in para. 210: 'A noninternational armed conflict is a confrontation between the existing governmental authority and groups of persons subordinate to this authority, which is carried out by force of arms within national territory and reaches the magnitude of an armed riot or a civil war.' The military handbook, Nolte (2003) summarises and compares military law in Belgium, Denmark, France, Germany, Italy, Luxembourg, the Netherlands, Poland, Spain and the United Kingdom. It reveals that the only state military law which expressly refers to its military manual as taking precedence over the general treaty interpretation of international humanitarian law, should such a manual explicitly define key terms, is that of France. France supports a broader interpretation of the scope of application of Common Art. 3. 
The judgments of national courts serve as helpful evidence for the practice of a particular state. ${ }^{197}$ Although there is no hierarchy with regard to the types of state practice, greater weight is given to the rulings of the higher courts than the lower courts. ${ }^{198}$ An example of such a case in the current context is the American case of Hamdan v. Rumsfeld. ${ }^{199}$ In this case, the United States Supreme Court (the highest court in the United States) offered an alternative textual interpretation of the geographical requirement of Common Article 3, which has the same practical implications as the suggested interpretation of the 2016 ICRC Commentaries referred to above. ${ }^{200}$ The accused, Hamdan, was an alleged Al Qaida affiliate captured in the context of an armed conflict between the United States and the de facto government of Afghanistan. ${ }^{201}$ It was suggested that two parallel conflicts existed at the time. ${ }^{202}$ The first conflict was categorised as an international armed conflict which was being fought between the United States and the Taliban (on behalf of Afghanistan). ${ }^{203}$

A second conflict concurrently existed between the United States and Al Qaida. ${ }^{204}$ The four Geneva Conventions applied with regard to the international armed conflict between the United States and Afghanistan. However, the conflict between the United States and Al Qaida fell outside the scope of regulation as it was between an organised armed group and a foreign state. At the same time, the conflict fell outside the scope of Common Article 3 if the interpretation were to be upheld that the geographic limitation limited the application of Common Article 3 to internal armed conflicts. ${ }^{205}$ The United States held the position that Common Article 3 applied only to internal armed conflict. ${ }^{206}$ The fact that the United States was involved in a 'transnational armed conflict' fighting Al Qaida left a lacuna in the regulation of this conflict. ${ }^{207}$ The United States Supreme Court responded to this lacuna by determining that Common Article 3 was to be given extra-territorial effect. ${ }^{208}$

The United States Supreme Court drew a comparison between the text of Common Article 2, which defines international armed conflict as a 'conflict between nations', and Common Article 3. ${ }^{209}$ Common Article 3 describes non-international armed conflict as 'an armed conflict not of an international character'. ${ }^{210}$ The Court compared these two phrases in

\footnotetext{
197 Germany v. Italy, above n. 169. The ICJ highlighted the paramount importance of national legislation as an indicator of state practice.

198 Ibid.

199 Hamdan v. Rumsfeld, Secretary of Defence et al, 548 US 557 (2006).

200 Ibid., para. 4(d)(ii).

$201 \quad$ Ibid.

202 Ibid. See also Milanovic and Hadzi-Vidanovic (2013), pp. 269-270.

$203 \quad$ Ibid.

$204 \quad$ Ibid

205 Ibid

$206 \quad$ Ibid. See also Pejic (2011), p. 202.

207 Ibid.

$208 \quad$ Ibid.; Pejic (2011), p. 201.

209 Ibid., at the opinion of Judge Stevens, para. 4. For an in-depth discussion of the Hamdan ruling, see Pejic (2011), pp. 201-203; Milanovic and Hadzi-Vidanovic (2013) pp. 269-271.

$210 \quad$ Ibid.
} 
an interpretative process comparable to a mathematic equation, ${ }^{211}$ and came to the conclusion that an armed conflict 'not of an international character', when juxtaposed with 'a conflict between nations', referred to those conflicts that are not fought between two or more states. ${ }^{212}$ 'Armed conflict not of an international character', thus, was considered by the United States Supreme Court to be a conflict fought between a single state and one or more organised armed groups or between multiple armed groups. ${ }^{213}$ This understanding of the phrase by the United States Supreme Court makes an assessment of the character of the armed conflict based on the parties involved, and does not consider whether there are any geographical requirements applicable to Common Article $3 .^{214}$

This analysis is open to criticism. ${ }^{215}$ This author disagrees with both the analysis and the judgment by the United States Supreme Court, but acknowledges that the motivation for this judgment perhaps was to fill a regulatory gap that would exist if neither the Geneva Conventions nor Common Article 3 applied to the situation. ${ }^{216}$ A general critique of the approach followed by the United States Supreme Court is that it considered an 'armed conflict not of an international character' to be a conflict fought between a single state and one or more organised armed groups or between multiple armed groups. ${ }^{217}$ This understanding of the phrase by the United States Supreme Court makes an assessment of the character of the armed conflict based on the parties involved, and does not sufficiently

\footnotetext{
211 Ibid. See also Milanovic and Hadzi-Vidanovic (2013), p. 270.

$212 \quad$ Ibid.

213 Ibid.

$214 \quad$ Ibid. See also Pejic (2011), p. 202.
}

215 Merely defining the term 'international armed conflict' negatively in order to determine the meaning of 'non-international armed conflict' fails to appreciate the minimum threshold requirements regarding the intensity of violence and the required degree of organisation of the military units of the parties to the conflict. In addition, this comparison ignored the phrase 'occurring in the territory of one of the High Contracting Parties'. Compare Milanovic and Hadzi-Vidanovic (2013), p. 270.

216 Initially, the United States did not apply Common Art. 3 extraterritorially. Common Art. 3 came to be applied to the conflict with Al Qaeda only after the Hamdan ruling by the United States Supreme Court. Prominent legal advisors in the United States question whether this ruling is correct but are of the view that the United States should have applied Common Art. 3 as a policy consideration to this conflict at an earlier stage. An earlier application would have facilitated more open debate concerning the shortcomings in Common Art. 3 in its ability to regulate extraterritorial armed conflict such as that between the United States and Al Qaeda. The Obama administration as a matter of policy adopted Art. 75 of Additional Protocol II to regulate the detention of non-state actors. The United States is not a party to Additional Protocol II and has questioned the outcome of the ICRC study on international humanitarian law which affords this provision customary status in the context of all armed conflicts. Therefore, this adoption is not a binding legal obligation but, in the words of a former legal advisor to the United States Department of State, as a result of a 'sense of legal obligation' it is applied. The Hamdan decision was not challenged in court, but this lack of a challenge does not mean that initially it was met with approval by the Department of State. However, it did consider the probable political and international 'backlash' which would result from the non-application of Common Art. 3 and that may have prevented the United States government openly questioning this ruling. A more restrictive interpretation is in the interest of the United States as that limits the possibility of law suits and gives it greater freedom concerning the operational conduct of its military. The United States has followed the Hamdan ruling and later administrations have avoided the difficulties experienced by the Bush presidency. The Hamdan decision has a place in this discussion but its importance should not be overstated (Bellinger and Padmanabhn (2011) and Bellinger, above n. 115).

217 Ibid. 
consider the level of intensity of the conflict. ${ }^{218}$ The Tadic formula has been widely accepted to serve as a benchmark that has to be satisfied in order for the law of armed conflict to be triggered. ${ }^{219}$ Even if the Court considered (though this is not clear) the violence as being sufficiently protracted, a close reading of the Tadic formula clearly reveals that this formulation applies to internal armed conflicts alone. In other words, the formula applies only when 'there is a resort to armed force between states or protracted armed violence between governmental authorities and organized armed groups or between such groups within a state. ${ }^{220}$

The unique definition of an 'armed conflict not of an international character' as adopted by the United States Supreme Court has not resulted in international criminal tribunals and courts deviating from the Tadic formula or to question its formulation. ${ }^{221} \mathrm{~A}$ further criticism is that the United States Supreme Court in its analysis did not devote sufficient consideration to the drafting history of the Geneva Conventions, which clearly restricts the scope of application of Common Article 3 to internal armed conflict alone. ${ }^{222}$ Thus, it is the opinion of the author that the United States Supreme Court erred in its interpretation of this provision. Nonetheless, the Hamdan case arguably is part of a process lending support to the broader interpretation of Common Article 3 which is gaining some traction. ${ }^{223}$

The approach of the Columbian Constitutional Court differs from Hamdan in its ruling of 2012, ${ }^{224}$ in which it confirmed that the Inter-American Court of Human Rights and this Court (the Columbian Constitutional Court) agree upon the geographic limitation in the context of Common Article 3, which the Inter-American Court followed in its 2007 ruling. $^{225}$ The Columbian Constitutional Court acknowledged that the ICRC's Authorised Commentary on the 1949 Geneva Conventions encourages the view that Common Article 3 should be applied as broadly as possible, but nevertheless confirmed that it followed the traditional understanding of the geographic scope of Common Article 3: 'Common Article 3 [...] does not actually define "an armed conflict not of an international character". However, it is

\footnotetext{
$218 \quad$ Ibid. See also Pejic (2011), p. 202.

219 Tadić, above n. 2, para. 70 (emphasis added). See cases listed at n. 17.

220 Tadić, above n. 2, para. 70 (emphasis added).

$221 \quad$ Cf. Shamir-Borer (2007), p. 610.

222 Ibid.

223 Sassòli (2006), p. 9 problematises a restrictive interpretation of the territorial application of Common Art. 3, as follows: 'According to the aim and purpose of IHL, this must be understood as simply recalling that treaties apply only to their state parties. If such groups and spreading over the territory of several states were not 'non-international armed conflicts', there would be a gap in protection which could not be explained by states' concerns about their sovereignty. Those concerns made the law of non-international armed conflict rudimentary. Yet concerns about state sovereignty could not explain why victims of conflicts spilling over the territory for several states should benefit from less protection than those affected by conflits limited to the territory of only one state.' Therefore, he is not opposed to the court's ruling in the Hamdan case and considers that there is sufficient judicial practice to suggest that 'internal conflicts are distinguished from international armed conflict by the parties involved rather than by the territorial scope of the conflict'. This approach followed in the Hamdan case was consistently included as the United States position in its 2015 US Department of Defense Law of War Manual as discussed in Sect. 3.2.1 of this article.

224 Judgment C-781 of 2012, para. 5.4.1, http://www.corteconstitucional.gov.co/RELATORIA/2012/C781-12.htm (accessed 2 August 2017).

$225 \quad$ Ibid., para. 5.4.1.
} 
generally understood that Common Article 3 applies to open and low-intensity armed confrontations between armed forces or relatively-organised groups occurring within the territory of a particular state'.226

On the whole, the above analysis reveals that at present only limited practice exists in support of the application of Common Article 3 to 'cross-border', 'transnational' and 'spillover' armed conflicts. The existing state practice does not meet the high benchmark test inherent in Article 31(3) of the Vienna Convention on the Law of Treaties which requires that state practice should be concordant, consistent and common. ${ }^{227}$ The ICRC does admit to this flaw in its argument, but clearly highlights that it is probable that state practice may over time develop sufficiently. ${ }^{228}$ The question arises as to whose practice should be considered in order to determine whether state practice is sufficient to influence treaty interpretation: ${ }^{229}$ Do all the signatories to the Convention have to be in agreement regarding the interpretation of a provision, ${ }^{230}$ or is the majority view, the opinion of a select number of states, or even a single state's interpretative practice and actions pursuant to its understanding of the relevant provision sufficient? ${ }^{231}$ How will inconsistencies in practice be resolved? ${ }^{232}$ Does the silence of certain parties infer their agreement that subsequent practice in a specific case has enlightened the meaning of a multilateral treaty provision ${ }^{233}$ Uncertainty concerning the answers to these questions prevails.

At present, state practice relating to the broader interpretation of the geographic requirement inherent in Common Article 3 is inconsistent. ${ }^{234}$ Therefore, the argument currently is unconvincing that state practice supports the broader interpretation of the phrase 'armed conflict not of an international character' that eliminates the geographical limitation. However, it is possible that sufficient state practice will evolve in support of this broader interpretation concerning the understanding of non-international armed conflict within the context of Common Article 3.

\section{Conclusion}

Historically, the existence and scope of a geographical requirement in terms of Common Article 3 received little or no attention in the effort to define and classify an armed conflict as a non-international armed conflict and, consequently, in determining the applicability of

\footnotetext{
226 Ibid.

227 See n. 136.

2282016 ICRC Commentaries, above n. 9, para. 121.

$229 \quad$ Nolte (2013), p. 47.

$230 \quad$ Gardiner (2008), pp. 235-238.

231 Ibid.

232 Cf. Nolte (2013), pp. 54 and 326. 'Divergent practice does not reflect an agreement between states.'

233 Gardiner (2008), pp. 235-238. See also Wood, above n. 168, para. 22.

234 This conclusion is inferred by a survey of the available military manuals of states party to the four Geneva Conventions. The author specifically examined whether states adopted new military manuals post-9/11 and whether any amendments to its understanding of the geographic requirement or definition of noninternational armed conflict and the scope of application of Common Art. 3 were made. See discussion at $n$. 198.
} 
Common Article 3. It is only recently, arguably prompted by the changing landscape of armed conflict post-9/11, that this requirement has been challenged. In recent years, terminology such as 'transnational armed conflict', 'spill-over' and 'cross-border armed conflict' has triggered the interest of the community of scholars as battlefield realities demand legal certainty concerning the classification of contemporary conflicts as well as whether international humanitarian law applies. This need for legal certainty has been highlighted by the ICRC, when it addressed the uncertainty concerning the possible geographical limitations inherent in Common Article 3 by restricting its application to internal conflicts alone. This 'geographic requirement' received no attention in its 1952 Commentaries.

This article addressed the question of the existence of a geographical requirement in three parts. First, it briefly illustrated the practical implications if the traditional understanding of the geographical requirement is followed, the most pertinent of which is the possible lacuna as far as protection is concerned under international humanitarian law for those participants present in territories falling outside the boundaries of the state where the initial non-international armed conflict originated and where the threshold requirements for the establishment of a separate non-international armed conflict have as yet not been met. Second, it illustrated that the traditional understanding of Common Article 3 makes a strong argument for the inclusion of a geographical requirement restricting the scope of application of Common Article 3 to internal armed conflicts alone. This author considered whether the evolutive interpretation of treaties, as endorsed by the European Court of Human Rights, displaces such an interpretation but found that it does not. Finally, the article explored the arguments made by the ICRC in its 2016 ICRC Commentaries promoting a broader interpretation of the wording 'armed conflict not of an international character' and 'occurring in the territory of one of the High Contracting Parties'. Although the author recognises the line of reasoning offered by the ICRC and scholars alike, she considers it to be incorrect and that the scope of application of Common Article 3 continues to be restricted to internal armed conflict. At present, the least convincing argument is that of subsequent practice. The ICRC acknowledges that sufficient practice does not exist, and a survey conducted in Sect. 4 of the article confirms this finding. However, the existence of such practice would be a plausible argument for deviating from the traditional understanding of the geographical requirement.

In summary, the established understanding of the geographical requirement inherent in Common Article 3 determines that an armed conflict not of an international character takes place inside the borders of a single High Contracting Party. This conventional reading of the phrases 'armed conflict not of an international character' and 'occurring in the territory of one of the High Contracting Parties' confines the Common Article 3 understanding of noninternational armed conflict to internal armed conflicts or classic civil war. The ICRC Commentary, however, highlights the fact that contemporary practice is putting this definition under some pressure and that it may evolve in the future. 


\section{References}

Arimatsu I, Choudhury M (2014) The legal classification of the armed conflicts in Syria, Yemen and Libya. Chatham House 1:1-43

Bartels R (2009) Timelines, borderlines and conflicts. International Review of the Red Cross (IRRC) 91:35-67

Bellal A (ed) (2015) The war report: armed conflict in 2014. Oxford University Press, Oxford

Bellinger JB, Padmanabhan VM (2011) Detention operations in contemporary conflicts: four challenges for the Geneva Conventions and other existing law. American Journal of International Law 105(2):201-243

Boothby WH (2012) The law of targeting. Oxford University Press, Oxford

Branch J (2011) Mapping the sovereign state: technology, authority, and systemic change. International Organisation 65(1):1-36

Brooks RE (2004) War everywhere: rights, national security law, and the law of armed conflict in the age of terror. Univ Pa. Law Rev 153:675-761

Brownlie I (2008) Principles of public international law. Oxford University Press, New York

Cassese A (1981) The status of rebels under the 1977 Geneva Protocol on Non-International Armed Conflicts. ICLQ 30:416-439

Corn G, Jensen ET (2000) Transnational armed conflict: a 'principled' approach to the regulation of counter-terror combat operations. Isr Law Rev 42(1):46-77

Corn GS, (2007) Hamdan, Lebanon, and the regulation of hostilities: the need to recognize a hybrid category of armed conflict. Vand J Transnat'l Law 40(2):295-355

Crawford E, Pert A (2015) International humanitarian law. Cambridge University Press, Cambridge

Crawford J (2007) The creation of states in international law. Oxford Scholarship Online. Oxford University Press, Oxford

Crawford J (2012) Brownlie's principles of public international law, 8th edn. Oxford University Press, Oxford

Cullen A (2004) The parameters of internal armed conflict in international humanitarian law. Univ Miami Int Comp Law Rev 12:189-229

Cullen A (2005) Key developments affecting the scope of internal armed conflict in international humanitarian law. Mil Law Rev 183:66-109

Cullen A (2010) The threshold of non-international armed conflict. In: Cullen A, The concept of non-international armed conflict in international humanitarian law. Cambridge University Press, New York, chapter 4, pp 117-138

Daskal JC (2013) The geography of the battlefield: a framework for detention and targeting outside the 'hot' conflict zone. Univ Pa Law Rev 161:1165-1234

Dinstein Y (2014) Non-international armed conflicts in international law. Cambridge University Press, Cambridge

Dörr O, Schmalenbach K (eds) (2012) Vienna Convention on the Law of Treaties: a commentary. Springer, Berlin, Heidelberg

Fleck D (2013) The law of non-international armed conflict. In: Fleck D (ed) The handbook of international humanitarian law, 3rd edn. Oxford University Press, Oxford, pp 12011221

Gardiner G (2008) Treaty interpretation. Oxford University Press, New York

Garraway C (2004) The use and abuse of military manuals. Yearbook of International Humanitarian Law 7:425-440 
Garraway C (2010) Military manuals, operational law and the regulatory framework of the armed forces. In: Hayashi $\mathrm{N}$ (ed) National military manuals on the law of armed conflict, 2nd edn. FICHL Publication Series No. 2. Torkel Opsahl Academic Epublisher, Oslo, pp 45-53

Giemulla EM, Weber L (2011) International and EU aviation law: selected issues. Kluwer Law International, Alphen aan den Rijn

Gray C (2012) The meaning of armed conflict: non-international armed conflict. In: O'Connell ME (ed) What is war? An investigation in the wake of 9/11. Martinus Nijhoff Publishers, Leiden, pp 69-96

Hailbronner M (2016) Laws in conflict: the relationship between human rights and international humanitarian law under the African Charter on Human and Peoples' Rights. African Human Rights Law Journal 16(2):339-364. http://www.ahrlj.up.ac.za/hailbronner-m. Accessed 25 October 2017

Haque AA (2016) The United States is at war with Syria (according to the ICRC's New Geneva Convention Commentary. http://www.ejiltalk.org/the-united-states-is-at-warwith-syria-according-to-the-icrc-new-geneva-convention-commentary/. Accessed 14 June 2016

Henckaerts J-M, Doswald-Beck L (eds) (2005) Customary international humanitarian law. ICRC, Cambridge University Press, New York, United States of America

Honko K (2016) The relationship between international humanitarian law and the European Convention of Human Rights, and their evolutive application in the context of armed conflicts. https://blogs.uta.fi/ecthrworkshop/2016/01/11/honko/. Accessed 25 October 2017

Jinks D (2003) September 11 and the laws of war. Yale J Int Law 28:1-49

Kress C (2010) Some reflections on the international legal framework governing transnational armed conflicts. JCSL 15:245-274

Kress C (2012) Reviews of books: The treatment of combatants and insurgents under the law of armed conflict by Emily Crawford; The concept of non-international armed conflict in international humanitarian law by Anthony Cullen; Extraterritorial use of force against non-state actors by Noam Lubell; The law of non-international armed conflict by Sandesh Sivakumaran. BYIL 83(1):145-169

Kretzmer D (2005) Targeted killing of suspected terrorists: Extra-judicial executions or legitimate means of defence? EJIL 16(2):171-212

Le Bouthillier Y (2011) Article 32: Convention of 1969. In: Corten O, Klein P (eds) The Vienna Conventions on the Law of Treaties: a commentary, vol I. Oxford University Press, New York, pp 841-863

Letsas G (2004) The truth in autonomous concepts: How to interpret the ECHR. EJIL:279375

Letsas G (2010) Strasbourg's interpretive ethic: Lessons for the international lawyer. EJIL 21(3):509-541

Letsas G (2013) The ECHR as a living instrument: its meaning and legitimacy. Constituting Europe: The European Court of Human Rights in a National, European And Global Context 2:106-141

Lubell N, Derejko N (2013) A global battlefield? Drones and the geographical scope of armed conflict. Journal of International Criminal Justice 11(1):65-88

Mikos-Skuza R (2012) International law's changing terms: 'war' becomes 'armed conflict'. In: O'Connell ME (ed) What is war? An investigation in the wake of 9/11. Martinus Nijhoff Publishers, Leiden, pp 19-30 
Milanovic M, Hadzi-Vidanovic V (2013) A taxonomy of armed conflict. In: White ND, Henderson C (eds) Research handbook on international conflict and security law: Jus ad bellum, jus in bello, and jus post bellum. Edward Elgar Publishing, Cheltenham, pp 256-314

Moir L (2003) The law of internal armed conflict. Cambridge University Press, Cambridge

Nolte G (ed) (2013) Treaties and subsequent practice. Oxford University Press, Oxford

O'Connell ME (2009) Combatants and the combat zone. University of Richmond Law Review 43:101-119

Nolte G (ed) (2003) European Military Law Systems. De Gruyter Recht, Berlin

Paust JJ (2016) Errors and misconceptions in the 2015. DOD Law of War Manual. https://ssrn.com/abstract=2712004. Accessed 14 June 2016

Pejic J (2011) The protective scope of Common Article 3: More than meets the eye. IRRC 93:189-225

Pictet JS (ed) (1960) The Geneva Conventions of 12 August 1949. International Committee of the Red Cross, Geneva

Radin S (2013) Global armed conflict? The threshold of extraterritorial non-international armed conflicts. International Law Studies 89:696-743

Radsan AJ (2007) The collision between Common Article Three and the Central Intelligence Agency. Catholic University Law Review 56(3):959-999

Reisman WM, Leitzau WK (1991) Chapter I: Moving international law from theory to practice: The role of military manuals in effectuating the law of armed conflict. In: Robertson HB Jr (ed) The law of naval operations. International Legal Studies, vol 64. Naval War College Press, Newport, RI, pp 1-18

Rogers APV (2010) The United Kingdom manual of the law of armed conflict. In: Hayashi N (ed) National military manuals on the law of armed conflict, 2nd edn. FICHL Publication Series No. 2. Torkel Opsahl Academic Epublisher, Oslo, pp 89-96

Sassòli M (2006) Transnational armed groups and international humanitarian law. HPCR Occasional Paper Series, pp 1-43

Schmitt M, Garraway HB, Dinstein Y (2006) The manual on the law of non-international armed conflict (with commentary). International Institute of Humanitarian Law, San Remo, 2006. Israel Yearbook of International Law 36:333

Schmitt MN (2014) Charting the legal geography of non-international armed conflict. Int Law Stud 90(1):1-19

Schoberl K (2015) The geographical scope of application of the conventions. In: Clapham A, Gaeta P, Sassòli M (eds) The 1949 Geneva Conventions: a commentary. Oxford University Press, New York, pp 67-84

Schondorf RS (2004) Extra-state armed conflicts: is there a need for a new legal regime? International Law and Politics 37(1):1-78

Shaw MN (1982) Territory in international law. NYIL 13:61-91

Shamir-Borer E (2007) Revisiting Hamdan v Rumsfeld's analysis of the laws of armed conflict. Emory Int Law Rev 21:601-619

Sivakumaran S (2014) The law of non-international armed conflict. Oxford University Press, Oxford

Sorel JM, Bore Eveno V (2011) Article 31: Convention of 1969. In: Corten O, Klein P (eds) The Vienna Conventions on the Law of Treaties: a commentary, vol I. Oxford University Press, New York, pp 804-837 
Turns D (2010) Military manuals and the customary law of armed conflict. In: Hayashi N (ed) National military manuals on the law of armed conflict, 2nd edn. FICHL Publication Series No. 2. Torkel Opsahl Academic Epublisher, Oslo, pp 65-77

Viljanen J (2015) The interpretation of the ECHR as a living instrument: demise of the margin of appreciation doctrine? http://blogs.uta.fi/ecthrworkshop/2015/12/07/rachaelita/. Accessed 16 October 2017

Villiger ME (2009) Commentary on the 1969 Vienna Convention on the Law of Treaties. Brill Nijhoff, Leiden

Vite S (2000) Typology of armed conflicts in international humanitarian law: legal concepts and actual situations. IRRC 91:69-94

Von Heinegg WH (2010) The German manual. In: Hayashi N (ed) National military manuals on the law of armed conflict, 2nd edn. FICHL Publication Series No. 2. Torkel Opsahl Academic Epublisher, Oslo, pp 109-118

Watkin K (2004) Controlling the Use of Force: A Role for Human Rights Norms in Contemporary Armed Conflict. The American Journal of International Law 98:1-34

Zegveld L (2002) Accountability of armed opposition groups in international law. Cambridge University Press, Cambridge 